\title{
Eutrophication and some European waters of restricted exchange
}

\author{
Paul Tett ${ }^{\mathrm{a}, *}$, Linda Gilpin ${ }^{\mathrm{a}}$, Harald Svendsen ${ }^{\mathrm{b}}$, Carina P. Erlandsson ${ }^{\mathrm{c}}$, \\ Ulf Larsson ${ }^{\mathrm{d}}$, Susanne Kratzer ${ }^{\mathrm{e}}$, Eric Fouilland ${ }^{\mathrm{f}}$, Carol Janzen ${ }^{\mathrm{g}}$, Jae-Young Lee ${ }^{\mathrm{a}}$, \\ Christian Grenz ${ }^{\mathrm{h}}$, Alice Newton ${ }^{\mathrm{i}}$, João Gomes Ferreira ${ }^{\mathrm{j}}$, Teresa Fernandes ${ }^{\mathrm{a}}$, \\ Serge Scory ${ }^{\mathrm{k}}$ \\ ${ }^{a}$ School of Life Sciences, Napier University, Edinburgh EH10 5DT, UK \\ ${ }^{\mathrm{b}}$ Geophysical Institute, University of Bergen, N-5007 and Norwegian Polar Institute, N-9296 Tromsø, Norway \\ ${ }^{\mathrm{c}}$ Department of Earth Sciences, Göteborg University, SM-405 30 Göteborg, Sweden \\ ${ }^{\mathrm{d}}$ Department of Systems Ecology, Stockholm University, SE-106 91 Stockholm, Sweden \\ ${ }^{\mathrm{e}}$ Department of Physical Geography and Quaternary Geology, Stockholm University, SE-106 91 Stockholm, Sweden \\ ${ }^{\mathrm{f}}$ SAMS, Dunstaffnage Marine Laboratory, Dunbeg, Oban Argyll PA37 4QA, UK \\ ${ }^{\mathrm{g}}$ School of Ocean Sciences, University of Wales, Bangor, Menai Bridge, Anglesey LL59 5EY, UK \\ ${ }^{\mathrm{h}}$ Station Marine d'Endoume, UMR 6535 CNRS - LOB, rue Batterie des Lions, F13007 Marseille, France \\ ${ }^{\mathrm{i}}$ IMAR - University of the Algarve, Campus de Gambelas, 8000-117 Faro, Portugal \\ ${ }^{\mathrm{j}}$ IMAR - DCEA-FCT, Universidade Nova de Lisboa, Monte de Caparica 2825, Portugal \\ ${ }^{\mathrm{k}}$ MUMM, Gulledelle 100, B-1200 Brussels, Belgium
}

Received 5 July 2002; accepted 30 June 2003

\begin{abstract}
Regions of Restricted Exchange (RREs) are an important feature of the European coastline. They are historically preferred sites for human settlement and aquaculture and their ecosystems, and consequent human use, may be at risk from eutrophication. The OAERRE project (EVK3-CT1999-0002) concerns 'Oceanographic Applications to Eutrophication in Regions of Restricted Exchange'. It began in July 2000, and studies six sites. Four of these sites are fjords: Kongsfjorden (west coast of Spitzbergen); Gullmaren (Skagerrak coast of Sweden); Himmerfjärden (Baltic coast of Sweden); and the Firth of Clyde (west coast of Scotland). Two are bays sheltered by sand bars: Golfe de Fos (French Mediterranean); and Ria Formosa (Portuguese Algarve). Together they exemplify a range of hydrographic and enrichment conditions. The project aims to understand the physical, biogeochemical and biological processes, and their interactions, that determine the trophic status of these coastal marine RRE through the development of simple screening models to define, predict and assess eutrophication. This paper introduces the sites and describes the component parts of a basic screening model and its application to each site using historical data. The model forms the starting point for the OAERRE project and views an RRE as a well-mixed box, exchanging with the sea at a daily rate $E$ determined by physical processes, and converting nutrient to phytoplankton chlorophyll at a fixed yield $q$. It thus uses nutrient levels to estimate maximum biomass; these preliminary results are discussed in relation to objective criteria used to assess trophic status. The influence of factors such as grazing and vertical mixing on key parameters in the screening model are further studied using simulations of a complex 'research' model for the Firth of Clyde. The future
\end{abstract}

\footnotetext{
*Corresponding author. Tel.: +44-131-455-2350; fax: +44-131-455-2291.

E-mail address: p.tett@ichrachan.u-net.com (P. Tett).
} 
development of screening models in general and within OAERRE in particular is discussed. In addition, the paper looks ahead with a broad discussion of progress in the scientific understanding of eutrophication and the legal and socioeconomic issues that need to be taken into account in managing the trophic status of RREs.

(C) 2003 Published by Elsevier Ltd.

\section{Introduction}

Section 1.1 of this long paper introduces the concept of eutrophication and the legislation to which it is related. Section 2 outlines the OAERRE project which seeks to improve both the understanding and prediction of eutrophication in coastal regions of restricted exchange. A description of each of the six study sites is followed in Section 3 by an explanation of the components of a simple 'screening' model used to give a preliminary assessment of trophic status for each site. A more detailed 'research' model is then used in Section 4 to give insight into some of the factors controlling key parameters in the simple model. This leads in Section 5 to a discussion of how to improve the screening model and develop links to the socio-economic impact of eutrophication and its amelioration.

\subsection{Eutrophication and environmental protection in regions of restricted exchange}

The contents of fjords, lagoons and rias are cut off from the normal circulation of coastal waters by enclosure on three sides, although there may be good exchange across the fourth side. Such Regions of Restricted Exchange (RREs) are an important feature of the European coastline, and the lands surrounding them are preferred sites for human settlement, using their waters for fisheries, aquaculture, navigation and recreation. These activities can lead to increased nutrient loading and hence the risk of eutrophication, which is intensified by restricted water exchange.

Most states and localities have their own laws and rules for protecting the environment within regions of restricted exchange. These have usually been drawn up to conform with a variety of European directives and other trans-national agreements. Those of particular importance in relation to eutrophication include: the Urban
Waste Water Treatment Directive (UWWTD: C.E.C., 1991a); the Water Framework Directive (WFD: C.E.C., 2000); the Oslo and Paris Convention for the protection of the Marine Environment of the North-East Atlantic (OSPAR); the Helsinki Convention (HELCOM) for the Baltic, and the Barcelona Convention for the Mediterranean.

The UWWTD deals with the treatment that urban waste water must receive before its discharge. Removal of organic matter is standard, but in the case of an eutrophic receiving water, treatment has to include additional stripping of plant nutrients. Basic treatment is permitted in the case of a 'less sensitive' water, defined as subject to high dispersion and hence not likely to be deoxygenated or eutrophied.

The WFD provides a single system that incorporates a variety of requirements for management of water status. In addition to specific protection of certain habitats, drinking water abstraction areas, and bathing waters, it requires that almost all waters have 'good ecological status' and 'good chemical status' by 2015, with no degradation being allowed if a water's current status is better than 'good'. 'Good ecological status' is defined as having a biological community that closely resembles that to be expected were the water body subject to minimal anthropogenic impact. 'Good chemical status' requires compliance with all EU water quality standards for chemical substances.

The WFD extends to at least one nautical mile beyond the coastal baseline for biological quality elements and 12 nautical miles for the physicochemical quality elements (including nutrients). So far as eutrophication is concerned, OSPAR has responsibility for all north-east Atlantic and North Sea waters beyond these limits, and is moving to harmonise its classification scheme with those of the WFD, by equating WFD 'good' and 'high' ecological status with OSPAR's 'non-problem 
area' (OSPAR, 2001b). "The overall goal of the OSPAR Strategy to Combat Eutrophication is to reach by 2010 a healthy environment where eutrophication does not occur", that is, to ensure that all Convention waters fall into the 'nonproblem area' category with respect to eutrophication by this time.

Eutrophic conditions were defined in the UWWTD (C.E.C., 1991a) as involving:

enrichment of water by nutrients especially compounds of nitrogen and phosphorus, causing an accelerated growth of algae and higher forms of plant life to produce an undesirable disturbance to the balance of organisms and the quality of the water concerned.

Vollenweider (1992) has given a similar definition in which the consequences of nutrient enrichment are enhanced primary production, leading, in serious cases, to visible algal blooms and algal scum. In contrast, Nixon (1995) considered only the first two elements (enrichment and accelerated growth) of the UWWTD characterisation and argued for a 'value-free' definition of eutrophic conditions, based on the level of annual primary production.

OSPAR (2001a) has proposed a set of assessment criteria covering: (i) degree of nutrient enrichment; (ii) direct effects of nutrient enrichment, including enhancement of phytoplankton chlorophyll and of the abundance of indicator species; (iii) indirect effects including oxygen depletion, changes/kills in zoobenthos, fish kills, and organic matter input to the sediment; and (iv) possible effects, including shellfish intoxication. In the case of freshwaters, an OECD scheme (OECD, 1982) evaluates trophic status on the objective basis of measurements of water transparency and levels of phosphorus and chlorophyll.

Eutrophic conditions are sometimes natural and long-standing, as in the case of marine upwelling regions, and most ecologists would not consider the ecosystems of such regions to be undesirably disturbed. An European example is the Canary Current upwelling region, where persistent upwelling of deep, nutrient-rich water supports high planktonic production and a rich fishery (Barton et al., 1998). In other cases, however, the eutrophic state is a recent result of nutrient enrichment due to human actions, and is associated with changes in water quality or the balance of organisms. The coastal waters of the southern North Sea provide an example of such changes. Nutrient enrichment of the inner part of the German Bight, in particular, has been linked to a well documented increase of the proportion of flagellated phytoplankton (Gillbricht, 1988) and has been held responsible for sea-bed deoxygenation (Gerlach, 1990).

\section{The OAERRE project}

\subsection{Introduction}

The OAERRE project concerns 'Oceanographic Applications to Eutrophication in Regions of Restricted Exchange'. It aims to understand the physical, biogeochemical and biological processes, and their interactions, involved in eutrophication in regions of restricted exchange, especially lagoons and fjords. Better knowledge of these processes is needed to diagnose, predict and manage the impact of anthropogenic nutrients on the ecosystem health, and sustainable use, of RREs. OAERRE uses oceanographic methods to gain this knowledge and to use it in coupled physical-biological models for RREs. The project's final objective is to construct simplified 'screening' models for the definition, assessment and prediction of eutrophication, in collaboration with end-users, and the use of these models to analyse the costs and benefits of amelioration scenarios.

OAERRE is a partnership amongst 12 institutions in Belgium, France, Norway, Portugal, Sweden and the UK, and commenced in July 2000. It is substantially funded by the Framework $\mathrm{V}$ programme of the European Commission, and is part of the ELOISE cluster of projects. Its efforts are focused on the sites listed in Table 1, and this paper makes a preliminary assessment of the trophic status of these sites. This allows us to demonstrate and discuss many of the issues raised by the use of screening models in OAERRE. 
Table 1

OAERRE sites and their main features

\begin{tabular}{|c|c|c|c|c|c|c|}
\hline $\begin{array}{l}\text { Site-Local name } \\
\text {-English name }\end{array}$ & $\begin{array}{l}\text { Kongsfjorden } \\
\text { Kings Bay }\end{array}$ & $\begin{array}{l}\text { Gullmaren } \\
\text { Gullmar fjord }\end{array}$ & $\begin{array}{l}\text { Himmerfjärden } \\
\text { Himmer fjord }\end{array}$ & Firth of Clyde & $\begin{array}{l}\text { Golfe de Fos } \\
\text { Fos gulf }\end{array}$ & Ria Formosa \\
\hline $\begin{array}{l}\text { Where (region or } \\
\text { nearest city) }\end{array}$ & West Spitzbergen & $\begin{array}{l}\text { West Sweden } \\
\text { (Göteborg) }\end{array}$ & $\begin{array}{l}\text { East Sweden } \\
\text { (Stockholm) }\end{array}$ & $\begin{array}{l}\text { West Scotland } \\
\text { (Glasgow) }\end{array}$ & $\begin{array}{l}\text { South France } \\
\text { (Marseille) }\end{array}$ & $\begin{array}{l}\text { South Portugal } \\
\text { (Algarve) }\end{array}$ \\
\hline $\begin{array}{l}\text { Latitude and } \\
\text { Longitude }\end{array}$ & $79^{\circ} \mathrm{N} 12^{\circ} \mathrm{E}$ & $58^{\circ} \mathrm{N} 11^{\circ} \mathrm{E}$ & $59^{\circ} \mathrm{N} 18^{\circ} \mathrm{E}$ & $55^{\circ} \mathrm{N} 05^{\circ} \mathrm{W}$ & $43^{\circ} \mathrm{N} 05^{\circ} \mathrm{E}$ & $37^{\circ} \mathrm{N} 08^{\circ} \mathrm{W}$ \\
\hline $\begin{array}{c}\text { Source water } \\
\left({ }^{*} \text { oceanic }\right)\end{array}$ & ${ }^{*}$ Greenland Sea & Skagerrak/Kattegat & $\begin{array}{l}\text { Baltic Sea (low } \\
\text { salinity) }\end{array}$ & Irish Sea & $\begin{array}{l}\text { *Western } \\
\text { Mediterranean }\end{array}$ & $\begin{array}{l}\text { *Atlantic-Bay of } \\
\text { Cadiz }\end{array}$ \\
\hline WFD ecoregion & Norwegian Sea & North Sea & Baltic Sea & Atlantic Ocean & Mediterranean Sea & Atlantic Ocean \\
\hline Basin type $\mathrm{a}^{\mathrm{a}}$ & $\begin{array}{l}\text { Broad fjord, deep } \\
\text { entrance with } \\
\text { Krossfjorden }\end{array}$ & Narrow fjord & $\begin{array}{l}\text { Microtidal 4-basin } \\
\text { fjord, narrow except } \\
\text { outer basin }\end{array}$ & $\begin{array}{l}\text { Broad fjord with } \\
\text { narrow fjords and } \\
\text { polls }\end{array}$ & Microtidal lagoon & $\begin{array}{l}\text { Lagoon with large } \\
\text { intertidal }\end{array}$ \\
\hline $\begin{array}{l}\text { Main drivers of } \\
\text { exchange }^{b}\end{array}$ & $\mathrm{~W}, \mathrm{E}$ & DI & DI, E & $\mathrm{E}, \mathrm{W}, \mathrm{T}, \mathrm{DI}$ & $\mathrm{W}, \mathrm{E}$ & $\mathrm{T}$ \\
\hline $\begin{array}{l}\text { Annual range of } \\
\text { mean air temp. }\left({ }^{\circ} \mathrm{C}\right)\end{array}$ & $-15(\mathrm{Feb}), 5(\mathrm{Jul})$ & $\begin{array}{l}0 \text { (winter) } \\
18 \text { (summer) }\end{array}$ & -2 (Feb), 16 (July) & 2 (Feb), 12 (Sep) & 8 (Feb), 24 (Jul) & $\begin{array}{l}12 \text { (winter), } \\
25 \text { (summer) }\end{array}$ \\
\hline $\begin{array}{l}\text { Min and max mean } \\
\text { precip. }(\mathrm{mm} / \text { month) }\end{array}$ & 20 (Jun), 40 (Sep) & 53 (annual mean) & 20 (Feb), 50 (Nov) & $\begin{array}{l}120 \text { (annual mean, } \\
\text { most in autumn) }\end{array}$ & 15 (Jul), 87 (Oct) & $\begin{array}{l}\text { (53 annual mean, } \\
\text { most in winter) }\end{array}$ \\
\hline Ice cover & variable, Feb-Apr & $\begin{array}{l}\text { Inner part, some } \\
\text { years, Feb-Mar }\end{array}$ & Part-whole, Jan-Mar & None & None & None \\
\hline Land use ${ }^{c}$ & G & $\mathrm{H}, \mathrm{U}(\mathrm{T})$ & $\mathrm{H}, \mathrm{F}, \mathrm{U}, \mathrm{T}$ & $\mathrm{U}, \mathrm{I}, \mathrm{F}, \mathrm{H}$ & $\mathrm{U}, \mathrm{I}$ & $\mathrm{U}(\mathrm{T}), \mathrm{F}$ \\
\hline Water use $^{\mathrm{d}}$ & $\mathrm{F}$ & $\mathrm{F}, \mathrm{A}, \mathrm{R}$ & $\mathrm{R}, \mathrm{N}, \mathrm{F}$ & $\mathrm{F}, \mathrm{N}, \mathrm{A}, \mathrm{R}$ & $\mathrm{A}, \mathrm{N}$ & $A, R$ \\
\hline
\end{tabular}

${ }^{\text {a }}$ Basin type: fjord is glacially overdeepened valley with entrance sill less than maximum depth of basin but sufficiently deep to allow 2-layer circulation (cf. 'poll', with shallow sill); lagoon is coastal bay protected by a bar of transported sediment. A broad fjord is wider than the local Rossby radius.

${ }^{\mathrm{b}}$ Circulation drivers, in order of importance; key: DI = density-driven intermediate exchange and deep-water flushing; $\mathrm{E}=$ estuarine (freshwater-driven) superficial circulation; $\mathrm{T}=$ tidal exchange; $\mathrm{W}=$ wind-driven (even dominated) exchange.

${ }^{\mathrm{c}}$ Land use, in order of importance; key: $\mathrm{F}=$ farming or silviculture involving fertilisation; $\mathrm{G}=$ glaciated and/or tundra; $\mathrm{H}=$ upland pasture or woodland without intensive cultivation; $\mathrm{I}=$ industrial; $\mathrm{U}=$ urban $(\mathrm{T}=$ strong seasonal-tourism component).

${ }^{\mathrm{d}}$ Water use (by humans, in order of importance); key: $\mathrm{A}=$ aquaculture (for fin- or shell-fish); $\mathrm{F}=$ fisheries (for fin- or shell-fish); $\mathrm{N}=$ navigation route for large vessels; $\mathrm{R}=$ recreation/tourism. 
For our purposes, a 'Region of Restricted Exchange' is defined as a water that is enclosed on three sides, so having restricted exchange with the sea; and in which the ratio of daily freshwater inflow to mean volume is less than 0.1 . The second part of the definition excludes estuaries that are strongly flushed as a direct result of river discharge. Although the first part specifies spatial restriction of exchange, it does not require the exchange to be small.

\subsection{Study sites: description}

The OAERRE study sites (Fig. 1) cover 42 degrees of latitude, from Kongsfjorden at $79^{\circ} \mathrm{N} 12^{\circ} \mathrm{E}$ on the western side of the island of Spitzbergen in the Svalbard archipelago, to the Ria Formosa at $37^{\circ} \mathrm{N} 8^{\circ} \mathrm{W}$ on the coast of the Algarve near Faro in southern Portugal.

Three sites are directly exposed to ocean water. The source water of Kongsfjorden reaches the fjord across a $50 \mathrm{~km}$ wide continental shelf from the Greenland Sea (Svendsen et al., 2002). Sustained ice cover is the rule at this latitude, but because of the northwards flow of warm Atlantic water in the West-Spitzbergen current, the offshore waters are mostly free of ice. Inner parts of the fjord freeze over during late winter, and the climate is sub-Arctic, mean air temperatures exceeding $0^{\circ} \mathrm{C}$ for less than 4 months. The Ria Formosa is a shallow lagoon (Caetano et al., 2002), taking its salt water across a $20 \mathrm{~km}$ continental shelf from the Gulf of Cadiz, a large bay of the Atlantic Ocean leading to the entrance to the Mediterranean Sea. The sea-water inflow to the Golfe de Fos, a shallow bay at $43^{\circ} \mathrm{N} 05^{\circ} \mathrm{E}$ near Marseille in southern France (Grenz, 2002), comes from the Northern Mediterranean Current as it flows westwards across the Gulf of Lions in the western Mediterranean (Millot, 1991). Further east, the continental shelf is very narrow $(<10 \mathrm{~km})$ but it broadens to $50 \mathrm{~km}$ offshore from Fos gulf. The climate of Provence and the Algarve is Mediterranean, with hot dry summers and rain falling mainly during the winter.

The other three sites communicate with coastal seas. Himmerfjärden, at $59^{\circ} \mathrm{N} 18^{\circ} \mathrm{E}$, near Stockholm in Sweden, takes its inflow from the low-

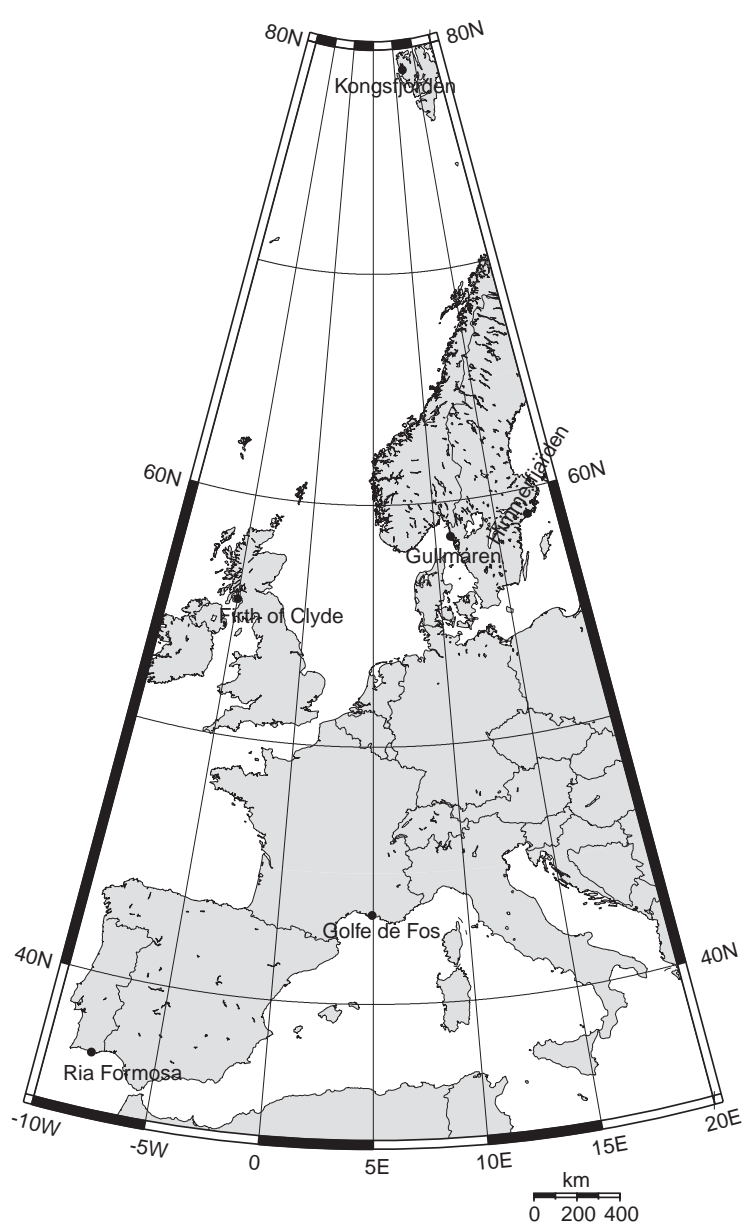

Fig. 1. Map showing location of OAERRE sites.

salinity waters of the Baltic Sea (Larsson and Kratzer, 2002), itself a giant fjord and prone to winter ice cover. Gullmaren, a fjord at $58^{\circ} \mathrm{N} 11^{\circ} \mathrm{E}$, north of Göteborg in western Sweden (Erlandsson and Arneborg, 2002), opens into the Kattegat, the strait communicating between the Baltic and the North Sea. The Firth of Clyde, a wide fjord at $55^{\circ} \mathrm{N} 05^{\circ} \mathrm{W}$ west of Glasgow in Scotland, has a sea-water inflow derived mainly from the Irish Sea (Edwards et al., 1986). It is subject to a mild, damp, maritime climate, which contrasts with the more continental regime experienced in eastern Sweden, where the Himmer fjord regularly freezes over during winter. Gullmaren is intermediate, with partial ice cover during some winters. 
Table 2

Hydrographic and nutrient loading data for the OAERRE sites

\begin{tabular}{|c|c|c|c|c|c|c|c|}
\hline & Site: & $\begin{array}{l}\text { Kongs } \\
\text { fjorden }\end{array}$ & $\begin{array}{l}\text { Gull } \\
\text { maren }\end{array}$ & $\begin{array}{l}\text { Himmer } \\
\text { fjärden }\end{array}$ & $\begin{array}{l}\text { Firth of } \\
\text { Clyde }\end{array}$ & $\begin{array}{l}\text { Golfe de } \\
\text { Fos }\end{array}$ & $\begin{array}{l}\text { Ria } \\
\text { Formosa }\end{array}$ \\
\hline Volume $^{\mathrm{a}}$ & $10^{6} \mathrm{~m}^{3}$ & 40000 & 2300 & 2850 & 100000 & 336 & 88 \\
\hline Surface area & $\mathrm{km}^{2}$ & 229 & 51 & 190 & 2500 & 42 & 58 \\
\hline Mean depth & $\mathrm{m}$ & 175 & 45 & 15 & 40 & 8 & 1.5 \\
\hline Maximum depth & $\mathrm{m}$ & 400 & 120 & 52 & 195 & 50 & 19 \\
\hline Max. entrance depth & $\mathrm{m}$ & 250 & 43 & 20 & 50 & 50 & 10 \\
\hline Freshwater inflow & $10^{6} \mathrm{~m}^{3} \mathrm{~d}^{-1}$ & 2.59 & 1.86 & 1.64 & 32.83 & 0.39 & 0.22 \\
\hline Freshwater rate $^{\mathrm{b}}$ & $10^{-6} \mathrm{~d}^{-1}$ & 65 & 808 & 576 & 328 & 1160 & 2460 \\
\hline (astronomical) Tide & & Semidiurnal & Semidiurnal & Negligible & Semidiurnal & Negligible & Semidiurnal \\
\hline (mean) Tidal prism & $10^{6} \mathrm{~m}^{3}$ & 240 & 13 & & 5800 & & 115 \\
\hline Tidal rate ${ }^{\mathrm{b}}$ & $10^{-3} \mathrm{~d}^{-1}$ & 12 & 11 & & 116 & & 2526 \\
\hline $\begin{array}{l}\text { Total land-derived } \\
\text { nutrient }^{\mathrm{c}}\end{array}$ & $\mathrm{kmol} \mathrm{d}^{-1}$ & & & & & & \\
\hline $\mathrm{N}$ & & 0.5 & 157 & 515 & 3170 & 22 & 84 \\
\hline $\mathrm{P}$ & & 0.05 & 2.4 & 8.1 & 304.0 & 1.2 & 1.9 \\
\hline $\mathrm{Si}$ & & & 108 & & 1184 & 11 & \\
\hline Nutrient/area & $\begin{array}{r}\mathrm{kmol} \mathrm{d}^{-1} \\
\mathrm{~km}^{-2}\end{array}$ & & & & & & \\
\hline $\mathrm{N}$ & & 0.0 & 3.1 & 2.7 & 1.3 & 0.5 & 1.5 \\
\hline $\mathrm{P}$ & & 0.00 & 0.05 & 0.04 & 0.12 & 0.03 & 0.03 \\
\hline $\mathrm{Si}$ & & & 2.1 & & 0.5 & 0.3 & \\
\hline \multicolumn{8}{|l|}{$\begin{array}{l}\text { Ratio to Golfe de } \\
\text { Fos }\end{array}$} \\
\hline Volume & & 119 & 7 & 8 & 298 & 1 & 0.3 \\
\hline Mean depth & & 22 & 6 & 2 & 5 & 1 & 0.2 \\
\hline Freshwater rate & & 0.06 & 0.70 & 0.50 & 0.28 & 1.00 & 2.132 \\
\hline
\end{tabular}

${ }^{a}$ Volumes, depths, areas, refer to mean sea-level and the entire basin (cf. Table 6).

${ }^{\mathrm{b}}$ Freshwater rate $=$ daily freshwater inflow $\div$ volume; tidal rate $=$ tides $/$ day $\times$ tidal prism $\div$ volume.

${ }^{\mathrm{c}}$ Daily rate of input of nutrients from all sources, including rivers, direct, and atmosphere, except the sea.

Freshwater inflow to the Kings fjord comes mainly from glacier melt, and is low in nutrients. The Gullmar and Himmer fjords, and the Firth of Clyde, receive river inflow enriched to moderate extent with agricultural and urban nutrients. The Firth of Clyde and Himmer fjord also receive the discharge of urban waste water with various degrees of treatment. The Fos gulf has an input of water, moderately rich in nutrients, from the river Rhône. River discharges into the Ria Formosa are relatively small, but there are direct inputs of urban waste water. The Ria Formosa stands out from the other sites in that a large part of it is exposed to the air during each tidal cycle.
All the sites have a background of scientific study: Gullmaren, and the Firth of Clyde in particular have been observed intermittently for much of the 20th century; and the ecological impact on the Himmer fjord of the discharge from a large sewage treatment plant has been studied since 1976 (Elmgren, 1997). Despite the considerable work done at each site, there remain gaps, which OAERRE aims to fill. In addition, assembling knowledge in a form for proper comparison is no trivial task, and needs to be informed by theory such as that discussed later in this paper. Table 2 gives a preliminary comparison of some key environmental features of the OAERRE sites 
based on data available at the start of the project. Kongsfjorden, Gullmaren, Golfe de Fos and Ria Formosa are treated as single entities. The Firth of Clyde is made up of one large basin, called the Arran deep, and smaller basins opening into it across sills of various depths. One of these is the 'Inner Firth of Clyde'. The Himmer fjord also comprises several basins. In most parts of the following text the several basins are aggregated together, but they are treated separately when conditions are obviously different, and in the application of models. In such cases a downstream basin is assumed to receive all inputs to the upstream basin in addition to its own inputs, neglecting losses such as denitrification.

\subsection{Criteria and preliminary assessment of trophic status}

Assessment of our sites must, therefore, deal with two issues. Is a site objectively eutrophic in that levels of certain water quality or ecological quality variables satisfy a defined condition? And, is a site subject to eutrophication in the sense of the C.E.C. definition which emphasises a process - we would argue, human-driven - culminating in undesirable effects? Of course, these two issues are not always separated. The undesirable effects might be quantified by a variable that forms part of the objective assessment, or the precautionary principle might be invoked to argue that the existence of objectively defined eutrophic status should always be assumed to be undesirable.

In this paper we focus on the first issue and on what we call 'objective' measures of trophic status: bulk variables that apply unambiguously to the entire pelagic ecosystem. Matters relating to indicator species, known effects such as deoxygenation and benthic changes, and arguable effects such as shellfish intoxication, require too much qualification to be immediately useful here, but will be touched on in the final discussion.

Table 3 gives some existing and proposed objective categorisation schemes for trophic status. Those based on primary production use a measure that is subject to both practical and interpretational difficulties. The OECD categorisation of fresh-waters cannot be applied as such to salt waters, since nitrogen rather than phosphorus is widely held to be the limiting nutrient in temperate coastal seas (Ryther and Dunstan, 1971; Taylor et al., 1995; Downing et al., 1999; but cf. Soederstroem, 1996; Thingstad et al., 1998) and because of other differences between fresh and salt waters (Hecky and Kilham, 1988). In general, static relationships between annual averages for nutrient loading and chlorophyll have been established for freshwater (Dillon and Rigler, 1974; Vollenweider, 1976; Schindler, 1977; Schindler et al., 1978) while nutrient-biomass relationships are more dynamic in the more highly dispersive marine environment. However, lakes with rapid flushing are comparable to marine systems in this respect (Foy, 1992). For the present, therefore, we use the Environmental Quality Standards (EQSs) proposed by the UK CSTT $(1994,1997)$, which identify winter levels of nutrient and summer levels of phytoplankton chlorophyll as the measurement variables. The relevant data for some of our sites are presented in Table 4. The UK EQSs may not be appropriate to all sites, and the proposal by OSPAR (2001a) to use thresholds based on $50 \%$ enhancement over 'background' winter nutrient and growing season chlorophyll concentrations, has some attractions. However, the concept of an objective trophic scale supports the present use of absolute EQS.

According to the maximum summer chlorophyll data given in Table 4, Gullmaren and Golfe de Fos may be considered eutrophic. However, these maximum values are occasional extremes, and typical summer chlorophyll at these sites is below

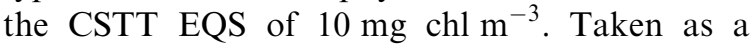
group, the OAERRE sites show little in the way of convincing relationships (Fig. 2) between typical chlorophyll and nutrient loading. In the case of the Himmer fjord, however, a plot of spring maximum chlorophyll on winter maximum DIN (Fig. 3) shows a good relationship (Larsson and Kratzer, 2002). The relationship emerges in part because the data set is large and extensive, based on observations at 5 stations between 1977 and 1994 . In addition, the slow flushing rate of the Himmer fjord may be expected to result in a better correlation between sequential events whereas 
Table 3

Objective criteria for trophic status

\begin{tabular}{|c|c|c|c|c|}
\hline Variable & Threshold & Units & Reference & Notes \\
\hline $\begin{array}{l}\text { (annual) Mean total } \\
\text { phosphorus }\end{array}$ & $>35.0$ & $\mu \mathrm{g}^{-1}$ & \multirow[t]{5}{*}{ OECD (1982) } & \multirow[t]{5}{*}{ For freshwaters } \\
\hline $\begin{array}{l}\text { (annual) Mean } \\
\text { chlorophyll }\end{array}$ & $>8.0$ & $\mu \mathrm{g}^{-1}$ & & \\
\hline Maximum chlorophyll & $>25$ & $\mu \mathrm{g} 1^{-1}$ & & \\
\hline $\begin{array}{l}\text { (annual) Mean Secchi } \\
\text { depth }\end{array}$ & $<3.0$ & $\mathrm{~m}$ & & \\
\hline $\begin{array}{l}\text { Minimum Secchi } \\
\text { depth }\end{array}$ & $<1.5$ & $\mathrm{~m}$ & & \\
\hline Winter DAIN ${ }^{\mathrm{a}}$ & $>12$ & $\mu \mathrm{M}$ & \multirow[t]{2}{*}{ CSTT $(1994,1997)$} & \multirow[t]{2}{*}{ For UK estuarine and coastal waters } \\
\hline Summer maximum chlorophyll & $>10$ & $\mu \mathrm{g}^{-1}$ & & \\
\hline $\begin{array}{l}\text { Winter DIN and/or } \\
\text { DIP }^{\mathrm{b}}\end{array}$ & $\begin{array}{l}>50 \% \text { above } \\
\text { background, with } \\
\text { defaults of }\end{array}$ & & \multirow[t]{5}{*}{$\begin{array}{l}\text { OSPAR (2001) } \\
\text { proposal }^{\mathrm{c}}\end{array}$} & \multirow[t]{4}{*}{$\begin{array}{l}\text { Background concs. are } \\
\text { region- and salinity-specific }\end{array}$} \\
\hline DIN & $>15$ & $\mu \mathrm{M}$ & & \\
\hline DIP & $>0.8$ & $\mu \mathrm{M}$ & & \\
\hline Winter $\mathrm{N} / \mathrm{P}$ ratio & $>25: 1$ & at:at & & \\
\hline $\begin{array}{l}\text { Growing season } \\
\text { chlorophyll }\end{array}$ & $\begin{array}{l}>50 \% \text { above } \\
\text { background }\end{array}$ & & & $\begin{array}{l}\text { Background concs. are } \\
\text { region-specific }\end{array}$ \\
\hline \multirow[t]{2}{*}{$\begin{array}{l}\text { Annual primary } \\
\text { production }^{\mathrm{d}}\end{array}$} & $>75$ & $\begin{array}{l}\mathrm{g} \mathrm{C} \mathrm{m}^{-2} \\
\mathrm{yr}^{-1}\end{array}$ & \multirow[t]{2}{*}{ Rodhe (1969) } & $\begin{array}{l}\text { 'naturally eutrophic' } \\
\text { freshwaters }\end{array}$ \\
\hline & $>350$ & & & 'Polluted' freshwaters \\
\hline $\begin{array}{l}\text { Annual primary } \\
\text { production }^{\mathrm{d}}\end{array}$ & $>300$ & $\begin{array}{l}\mathrm{g} \mathrm{C} \mathrm{m} \mathrm{m}^{-2} \\
\mathrm{yr}^{-1}\end{array}$ & Nixon (1995) & Sea \\
\hline
\end{tabular}

${ }^{a}$ DAIN = 'dissolved available inorganic nitrogen', effectively the same as the common usage of DIN and DTP.

${ }^{\mathrm{b}} \mathrm{DIN}=$ 'dissolved inorganic nitrogen' (which ought to include dissolved nitrogen gas); DIP $=$ dissolved inorganic phosphorus.

'Only selected, 'bulk', assessment parameters in OSPAR categories I and II are included.

${ }^{\mathrm{d}}$ The papers cited imply that this is 'net' primary production.

other sites are influenced by under-sampling and inherent patchiness.

\section{A simple screening model for eutrophication}

\subsection{Introduction}

The simplest models for eutrophication aim only to predict the value of an easily observed variable such as phytoplankton chlorophyll. We refer to them as 'screening models', on the grounds that they can be used to screen sites for actual or potential eutrophication. In addition, they provide a conceptual framework for elaboration of the factors controlling eutrophication.

The model presented in this section was originally developed by the UK's 'Comprehensive Studies Task Team' (CSTT, 1994, 1997; Tett, 2000) from a study of the yield of phytoplankton chlorophyll from DAIN in sea-water. This study (Gowen and Ezzi, 1992; Gowen, 1994) was designed to aid the prediction and management of the effects of nutrient enrichment of sea-water by aquaculture (GESAMP, 1996); the CSTT's brief arose from the need to define the 'comprehensive studies' that are required to be carried out under article 6 of the UWWTD to justify the discharge of waste water after only primary 
Table 4

Nutrient and chlorophyll statistics for the OAERRE sites

\begin{tabular}{|c|c|c|c|c|c|}
\hline \multirow[t]{2}{*}{ Site } & \multirow{2}{*}{$\frac{\text { Maximum }}{\mu \mathrm{M} \text { DAIN }}$} & \multirow{2}{*}{$\begin{array}{l}\text { winter } \\
\mu \mathrm{M} \text { DAIP }\end{array}$} & \multirow{2}{*}{$\begin{array}{c}\text { nutrient } \\
\mu \mathrm{M} D S i\end{array}$} & \multirow{2}{*}{$\begin{array}{l}\text { Maximum } \\
\text { Spring } \mu \mathrm{g} \mathrm{chl} 1^{-1}\end{array}$} & \multirow{2}{*}{$\begin{array}{l}\text { phytoplankton } \\
\text { Summer } \mu \mathrm{g} \text { chl } 1^{-1}\end{array}$} \\
\hline & & & & & \\
\hline Kongsfjorden & 12 & 0.8 & 6 & 5 & 3 \\
\hline Gullmaren & 10 & 0.9 & 13 & 25 & 20 \\
\hline \multicolumn{6}{|l|}{ Himmerfjärden } \\
\hline (a) Outer & 15 & 0.8 & 20 & 13 & 3 \\
\hline (b) Inner & 28 & 1.0 & 25 & 21 & 5 \\
\hline \multicolumn{6}{|l|}{ Firth of Clyde } \\
\hline (a) Main basin & 12 & 1.2 & 10 & 10 & 5 \\
\hline (b) Inner Firth & 25 & 1.7 & 18 & 7 & 5 \\
\hline Golfe de Fos & 25 & 2.0 & 25 & 22 & 10 \\
\hline Ria Formosa & 38 & 1.5 & 35 & 2 & 2 \\
\hline
\end{tabular}

DAIN = dissolved available inorganic nitrogen; the total of ammonium, nitrite and nitrate, also called DIN. DAIP $=$ dissolved available inorganic phosphorus; mainly phosphate, also called DIP. DSi = dissolved silica (silicate). Chlorophyll estimated by standard survey methods involving organic extraction and spectrophotometric or fluorometric measurement including step to distinguish pheopigment. Maximum values are typical greatest means for the superficial waters of the RRE basin during the relevant season: 'winter' is the period before the Spring Bloom, 'spring' includes the first major bloom, and 'summer' includes early autumn. Sources of data and details of subdivisions Kongsfjorden: Hop et al. (2002). Gullmaren: Lindahl (1987, 1994) and Svansson (1984). Himmerfjärden: Larsson and Kratzer (2002), Elmgren and Larsson (Eds.) (1997); (a) (outer) basin 1 (Svärdsfjärden) - mostly station H2; (b) proper (basins 2 +3) + basin 4: mostly stations H4 and H5. Firth of Clyde: (a) Arran Deep, or main, basin: Jones et al. (1995); (b) Inner Firth: Bock et al. (1999). Golfe de Fos: Benon et al. (1977), Folack (1986) and Arfi et al. (1990). Ria Formosa: nutrients are upper $90 \%$ ile values from IMAR data base.

treatment. The CSTT model treats RREs as wellmixed boxes (Fig. 4) of volume $V \mathrm{~m}^{3}$. All interaction with the sea is described by a single parameter, the daily fractional rate $E$ at which RRE contents are replaced by either salt or fresh water.

The CSTT model is a steady-state simplification of a dynamic model. The latter's key equations, which adapt the 'Riley+' model of Tett and Wilson (2000) to RRE conditions, are:

$$
\begin{aligned}
& \text { (chlorophyll) } \frac{\mathrm{d} X}{\mathrm{~d} t}=(\mu-L) X-E\left(X-X_{0}\right) \\
& -\frac{F}{V} X_{0} \mathrm{mg} \mathrm{chl} \mathrm{m}{ }^{-3} \mathrm{~d}^{-1},
\end{aligned}
$$

(limiting nutrient) $\frac{\mathrm{d} S}{\mathrm{~d} t}=-\frac{\mu \cdot X}{q}+e \frac{L \cdot X}{q}$

$$
\begin{gathered}
-E\left(S-S_{0}\right)+\frac{s_{i}}{V} \mathrm{mmol} \mathrm{m}^{-3} \mathrm{~d}^{-1}, \\
\text { where } s_{i}=F\left(S_{f}-S_{0}\right)+s_{i}^{\prime} .
\end{gathered}
$$

The subscript 0 refers to the concentration of nutrient $S$ or phytoplankton chlorophyll $X$ in the sea outside the RRE and $\mu$ is phytoplankton growth rate $\left(\mathrm{d}^{-1}\right) . L$ is phytoplankton loss rate $\left(\mathrm{d}^{-1}\right)$ due to causes such as grazing by copepods or benthic animals, phytoplankton sinking, or disease, and $e$ gives the fraction of the nutrient element content of such lost material that is recycled. A key parameter is $q$, the yield of chlorophyll from assimilated nutrient (Gowen et al., 1992). The RRE is enriched by $s_{i}$ moles of nutrient per day from local sources, which includes freshwater input at rate $F\left(\mathrm{~m}^{3} \mathrm{~d}^{-1}\right)$ and nutrient concentration $S_{f}$, and other supplies $s_{i}^{\prime}$.

The fundamental assumption of the CSTT and the dynamic model is that the box is uniform both horizontally and vertically. In fact, some spatial variation can be tolerated so long as model variables and parameters are appropriately averaged, but in the case of a well-stratified system, $E$ and $V$ apply to the upper waters only of the RRE.

Eq. (2) can be solved for the equilibrium enhanced concentration of nutrient in the RRE in the absence of local consumption by phytoplankton or phytobenthos, or losses (due e.g. to 

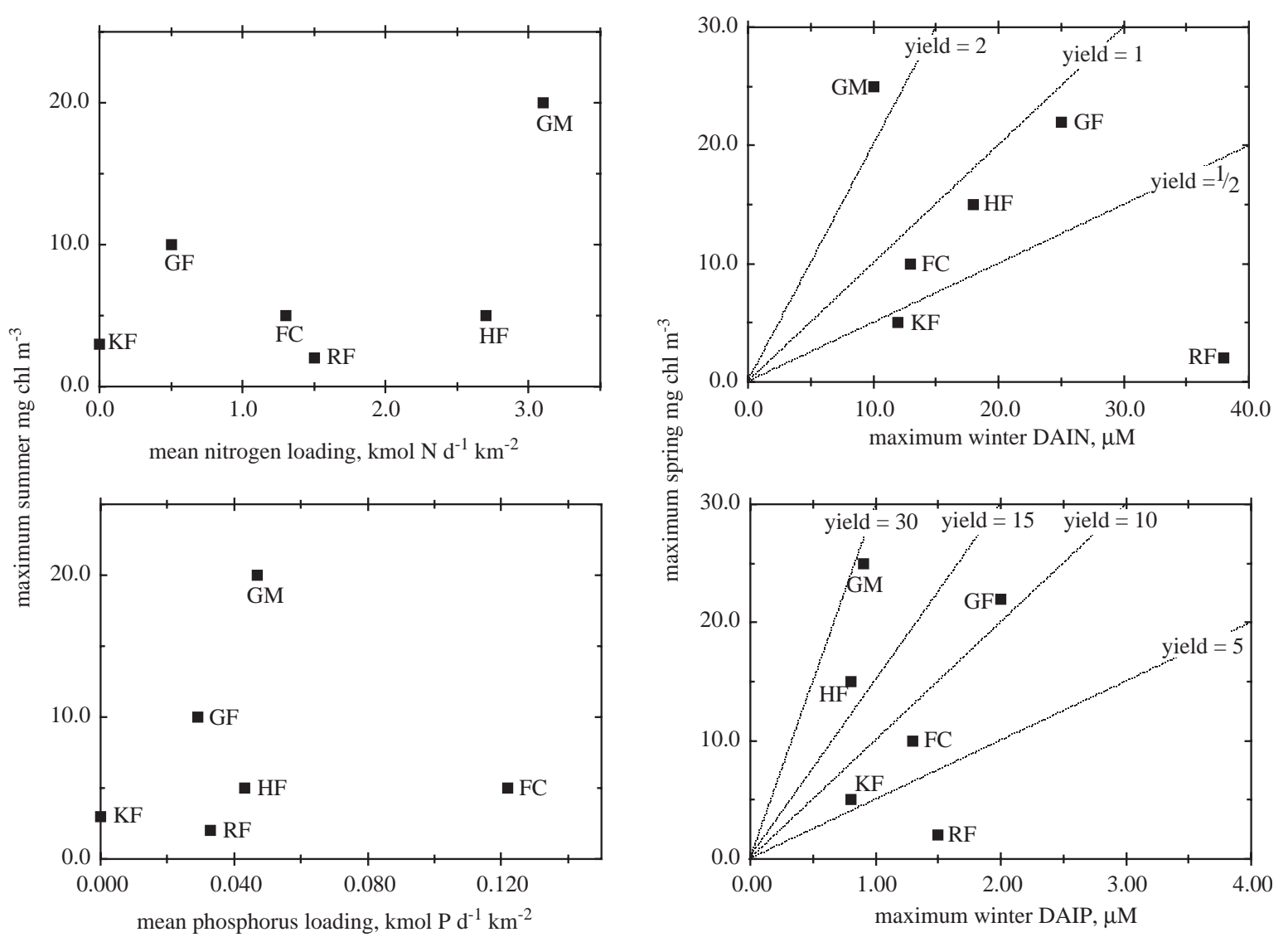

Fig. 2. Relationship between nutrient loading and phytoplankton chlorophyll statistics for the OAERRE sites.

denitrification). It is

$S_{e q}=S_{0}+\left(s_{i} /(E V)\right) \mathrm{mmol} \mathrm{m}^{-3}$.

This equation is similar to that of Gillibrand and Turrell (1997) who evaluated the effect of fish farm nutrients by comparing the Equilibrium Concentration Enhancement $\left(\mathrm{ECE}=s_{i} /(E V)\right.$ with a reference level. The CSTT model additionally considers the worst outcome, in which all of the nutrient is converted to phytoplankton, resulting in a maximum chlorophyll concentration:

$X_{\max }=X_{0}+q S_{e q} \mathrm{mg} \mathrm{chl} \mathrm{m}{ }^{-3}$.

The calculation is made for DAIP as well as DAIN, and the lower of the resulting values of $X_{\max }$ taken to define the maximum biomass and also to indicate the limiting nutrient element. The definitive value of $X_{\max }$ can be compared with an
EQS, such as the CSTT's threshold of $10 \mathrm{mg} \mathrm{chl} \mathrm{m}{ }^{-3}$ in summer for eutrophic conditions. However, a complete conversion of nutrient into chlorophyll can only occur if other factors allow sufficient growth of phytoplankton. High losses, or lack of light for growth, might prevent increase. Thus, it is required that

$$
\begin{gathered}
\mu(\overline{\bar{I}}) \gg\left(L+E\left(1-\left(1+\frac{F}{V}\right) \frac{X_{0}}{X}\right)\right) \mathrm{d}^{-1} \\
\text { or : } \mu(\overline{\bar{I}}) \geqslant(L+E) \text { as } X \rightarrow X_{\max } \quad \text { with } \\
X_{\max } \gg X_{0}
\end{gathered}
$$

for the high biomass to be achieved. The lightcontrolled rate of phytoplankton growth is

$\mu(\overline{\bar{I}})=\alpha^{B}\left(\overline{\bar{I}}-I_{c}\right) \mathrm{d}^{-1}$, 

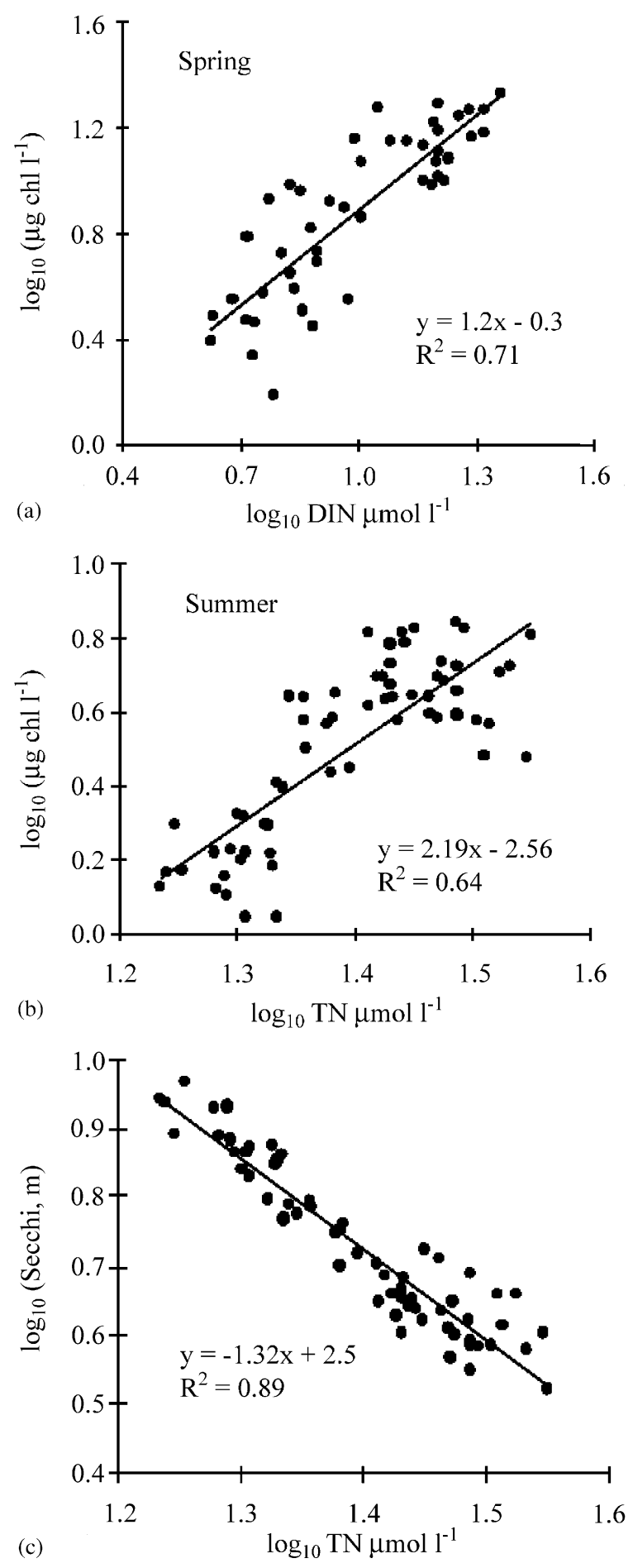

inputs from land, rivers, discharge, air

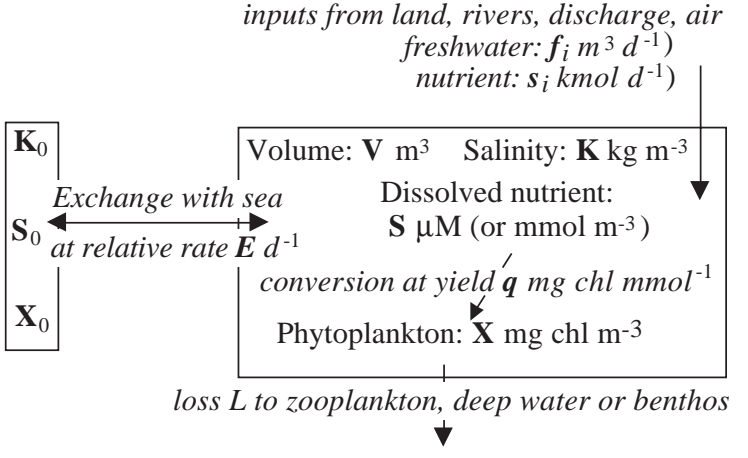

Fig. 4. Schematic of the CSTT's simple model for eutrophication.

where $\alpha^{B}$ is effective photosynthetic efficiency $\left(\mathrm{d}^{-1} \mathrm{I}^{-1}\right)$ at low illumination. The variable $\overline{\bar{I}}$ is Photosynthetically Available Radiation (PAR) averaged over $24 \mathrm{~h}$ for a typical summer's day and also averaged from sea surface to sea-bed, or from surface to pycnocline if stratification exists. In principle, the PAR should be that under high biomass conditions, because chlorophyll is itself a strong absorber of light. Finally, $I_{c}$ is compensation PAR, the illumination at which photosynthesis and respiration are in balance when totalled over $24 \mathrm{~h}$.

Eqs. (3)-(6) define the CSTT model and are (apart from minor changes in symbols) as given by CSTT (1994, 1997); however, the interpretation of the parameters, and the values assigned to them, have been improved since the original publications. The next 5 subsections explore these improvements in the context of OAERRE sites.

Fig. 3. Relationship between nitrogen and trophogenic layer properties in the Himmer fjord (Larsson and Kratzer, 2002) based on data from 5 stations during 1977-1994. (After Larsson (1997) with two more years of data added). (a) Maximal spring chlorophyll a concentration as a function of maximum inorganic nitrogen concentration in January/February, before the start of the spring bloom. Data from stations with inorganic $\mathrm{N} / \mathrm{P}$ atom ratios above 22 in winter have been excluded. (b) Annual mean chlorophyll a concentration as a function of total nitrogen concentration. (c) Yearly mean Secchi depth as a function of total nitrogen concentration. 


\subsection{Exchange}

The exchange rate, $E$, is the instantaneous probability that any small packet of water, containing salt, nutrients and phytoplankters, will be lost from the RRE to the sea and replaced by a packet of the same volume but having a different content of salt, nutrients and phytoplankters. The replacement may come either from the sea or from river discharge, rainfall, ice-melt, etc. The replacement probability is expressed as a daily rate after averaging over subdiel, especially tidal, fluctuations. The rate can be estimated in several ways, the best-known (Officer, 1976) involving conservation of salt:

$\frac{\mathrm{d}(\bar{C} V)}{\mathrm{d} t}=(E V-F) C_{0}-E V \bar{C} \mathrm{~kg} \mathrm{~d}^{-1}$,

where $F$ is freshwater input $\left(\mathrm{m}^{3} \mathrm{~d}^{-1}\right), \bar{C}$ is RRE mean salinity, and $C_{0}$ is external salinity. This has a steady-state solution:

$E=\frac{F}{V} \frac{C_{0}}{C_{0}-\bar{C}} \mathrm{~d}^{-1}$

and also allows the possibility of estimation from time-series of $\bar{C}$ and $F$. Other empirical methods include observing the dilution of an added tracer, constructing budgets for nutrients during seasons of little phytoplankton growth, and measuring currents in the entrance to a RRE. Theoretical methods involve understanding and evaluating the main processes involved in exchange between RREs and the sea.

Exchange between the upper layers of Kongsfjorden and the sea results from circulations driven by local wind and freshwater (Svendsen et al., 2002). Both circulations have a strong lateral component because the fjord's width exceeds the local Rossby radius (which is small at $79^{\circ} \mathrm{N}$ ). The wind-driven circulation is highly variable, depending on the wind strength and direction. In contrast, freshwater input from glacier melting occurs throughout the year, and so the freshwater-driven circulation is persistent, although stronger in summer. Observations of drifters, acousticallydetermined currents, and modelling, suggest a residence time for the upper layers of 1-2 weeks. The intermediate and deep layers of Kongsfjorden are largely isolated from surface flows by a strong pycnocline. These deeper waters exchange with the sea as a result of somewhat circular tidal flows as well as external changes in water density relative to the same depth inside the fjord.

The residence time of water above sill depth in Gullmaren has been estimated as about 1 week, giving an exchange rate of $0.1 \mathrm{~d}^{-1}$ (Erlandsson and Arneborg, 2002). Tidal flushing and freshwaterdriven 'estuarine' circulation account for little of this exchange. The main parts are due to (i) fluctuations in density surfaces linked to changes in the Skagerrak-Kattegat channel, and (ii) wind, causing both local circulation and internal seiches. Erlandsson and Arneborg (2002) distinguish two main layers in Gullmaren above sill depth: from 1 to about $15 \mathrm{~m}$ is Kattegat water, and beneath this, from 15 to $50 \mathrm{~m}$, is denser (saltier) Skagerrak water. The depth of the interface between the two waters responds to changes in conditions outside the fjord as well as to internal seiches. Every time that the interface moves up, water is drawn into the fjord below the interface, and pushed out above it. When the interface moves down, superficial water is drawn in and deeper water is pushed out. Because the residual circulation in the Skagerrak-Kattegat channel removes expelled water, the pumping from within Gullmaren results in effective exchange. Finally, the deepest water in Gullmaren is also drawn from the Skagerrak, but is replaced only about once during most years.

Water exchange in the 4-basin Himmer fjord is primarily driven by fresh-water inflow, which sets in motion an upper-layer estuarine circulation, and by density changes at the interface with the Baltic Sea, which drive an intermediate circulation leading to intermittent replacement of deep water (Engqvist, 1997; Larsson and Kratzer, 2002). In the outermost basin the intermediate circulation is roughly twice the estuarine circulation. The youngest water, 30 days old according to a numerical model, is found at $10 \mathrm{~m}$ depth, whereas the age of surface and deep waters is, typically, 50 days. In the innermost basin the surface water, with a mean age of 100 days, is youngest, the deep water having an age of 150 days. The weak circulation is a result of the relatively small freshwater input, and the presence of several sills. 
The ages are the number of days since the water left the Baltic Sea outside the fjord.

The Firth of Clyde exhibits complex physics with seasonal variability. Its Arran Deep basin is almost always stratified due to a combination of thermal and freshwater buoyancy inputs, with strongest layering occurring during spring and summer. Although tides are strong in the North Channel of the Irish Sea, much of the tidal energy is dissipated over the entrance sill (called the 'Great Plateau' in Fig. 7) resulting in weak tides in the Firth, and the establishment on the sill of a strong tidal mixing front separating the stratified Arran Deep from the well-mixed North Channel. Tidal, estuarine and wind-driven circulations show lateral variations along the sill of this broad fjord, and the presence of the tidal mixing front suppresses the cross-sill exchanges between the Arran Deep and the North Channel (Janzen et al., 2002). It is known that North Channel water can renew Arran Deep bottom water when the North Channel water is sufficiently dense to sink beneath the density front at the sill (Edwards et al., 1986; Rippeth, 1993). This renewal tends to occur in late Autumn or Winter, when freshwater discharge and solar heating are least, weakening vertical stratification in the Arran Deep and the tidal mixing front. The front moves only about $3-4 \mathrm{~km}$ between Neap and Spring tides (Kasai et al., 1999), which probably contributes little to exchange when the front lies over the sill. However, non-tidal movements of the front, on the order of $10 \mathrm{~km}$, may bring it far enough into the Clyde to allow exchange between the mixed and stratified regimes during Spring and Summer. Wind forcing might also contribute to cross-sill exchanges of waters (Midgely, 1998). Based on annual balances of mass flux, the estimated average residence time of water in the entire Firth of Clyde is 3-4 months (Midgely et al., 2001), at the upper end of the earlier estimate of 'several months' given by Edwards et al. (1986) and compatible with estimates of freshwater replacement times of between 62 and 150 days by Muller et al. (1995).

The gulf of Fos is a shallow microtidal system (Grenz, 2002) flushed weakly by an estuarine circulation driven by freshwater in the Rhône canal, and, intermittently but more strongly, by wind-driven lateral circulation. Whereas the estuarine circulation might flush the gulf over a period of 20 days (Tett and Grenz, 1994), highresolution 3-D model simulations suggest that the wind-driven circulation can replace water in the outer part of the gulf within a few days, and can isolate water of the inner part within a gyre (Ulses, 2002).

The Ria Formosa is a coastal lagoon with a large inter tidal zone, and $50-75 \%$ of the water in the lagoon is exchanged each tide. Although it is an RRE according to our definition, water residence times are very short, except perhaps for water in the inner parts of the drainage channels, and some interstitial water in intertidal sediments (Caetano et al., 2002).

This survey shows the variety of processes involved in water exchange between RREs and the sea, and thus emphasises the empirical and bulk nature of the exchange rate parameter $E$. Table 6 includes estimates of typical values of $E$ for the upper layer at each of our sites, obtained by a variety of methods. The estimates will be improved by the physical oceanographic studies carried out during OAERRE.

\subsection{Biological production and loss}

The Riley + model and its CSTT derivative try to distil the essence of pelagic biological processes into a few simple equations. Thus, light-controlled growth is described by Eq. (5) as the product of a constant photosynthetic efficiency and the excess of mean PAR over a compensation PAR. Typically, the relationship between photosynthesis $\left(p^{B}\right)$ and PAR $(I)$ is described by a curve (Jassby and Platt, 1976; Lederman and Tett, 1981), but a linear relationship is an acceptable approximation under low-light conditions (Tett, 1990). Thus,

$$
\begin{aligned}
\mu= & p_{m}^{B} \frac{I}{\sqrt{k_{I}^{2}+I^{2}}}-r \text { becomes : } \mu=\alpha^{B}\left(I-I_{c}\right) \\
& \text { where } \alpha^{B}=\frac{p_{m}^{B}}{I_{k}} \text { and } I_{c}=\frac{r}{\alpha^{B}} \\
& r \text { being respiration rate. }
\end{aligned}
$$

The photosynthetic efficiency parameter $\alpha^{B}$ is more fundamental than either the maximum 
photosynthetic rate $p_{m}^{B}$ or the 'saturation' irradiance $I_{k}$, as the efficiency is directly related to the quantum yield of photosynthesis and the (PAR) absorption cross-section of photosynthetic pigments.

As discussed elsewhere (Tett, 1990; Tett et al., 2002), the use of algal values (derived from laboratory measurements of single-species populations) for the parameters in Eq. (9), leads to overprediction of growth rate. In fact, some primary production is rapidly lost due to predation of algal cells by protozoans and the mineralisation of excreted organic matter by pelagic bacteria. Such microbial loop losses are distinguished from those to mesozooplankton and benthos in the microplankton model (Tett, 1998) which is used as the theoretical basis for the parameters in the CSTT model. In this model (Fig. 5), nitrogen and phosphorus are considered to be efficiently recycled within the microbial loop, whereas protozoan and bacterial respiration are deemed to augment phytoplankton respiration. The micro-

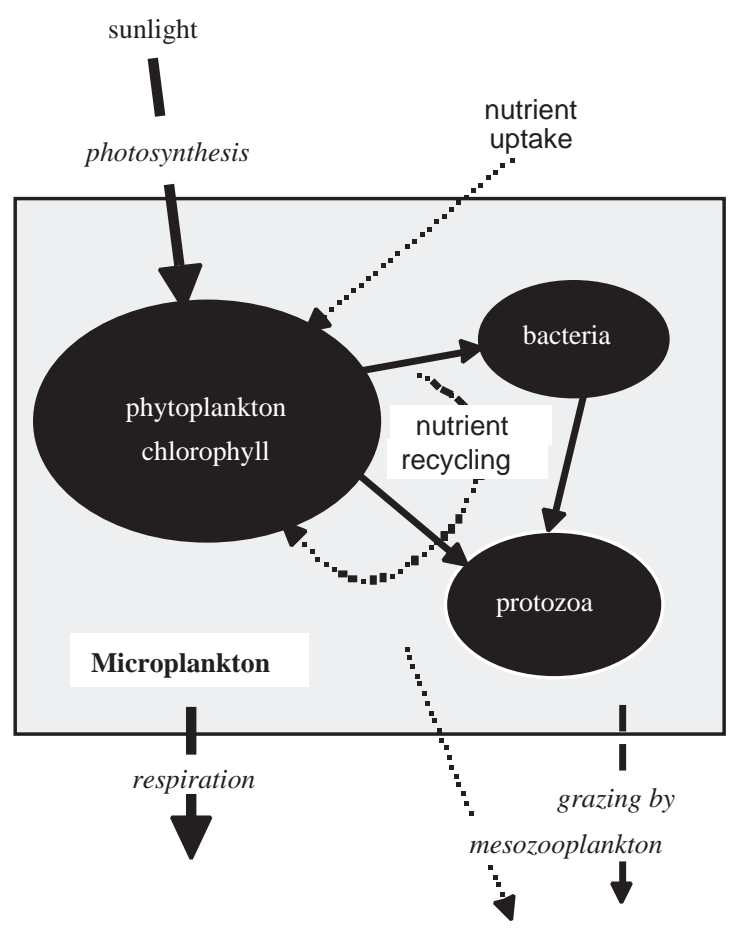

Fig. 5. The microplankton box. plankton is, thus, seen as consisting of a microheterotrophic component (eubacteria and protozoa) and an autotrophic component (the phytoplankton) which are assumed to be in at least short-term balance with each other (see Tett and Wilson, 2000). The effect of microheterotrophs in increasing respiration, and in diverting nutrient elements from algae into protozoa or bacteria, is parameterised by means of the heterotroph fraction $(\eta)$, the ratio of microheterotroph carbon biomass to total microplankton biomass.

The microplankton model, and the present version of the CSTT model, assume that microplankton respiration increases with microplankton growth rate:

$r=r_{0}+b \mu \mathrm{d}^{-1}$

but has no temperature dependence.

The effective photosynthetic efficiency of Eq. (9) must also take account of the ratio of algal chlorophyll to total microplankton (organic carbon) biomass as well as the need to support microheterotroph metabolism:

$\alpha^{B}=\frac{\alpha_{m} \chi}{1+b}$,

where microplankton $\mathrm{chl}: \mathrm{C}$

ratio is : $\chi={ }^{X} q_{a}^{N}\left(Q-q_{h} \eta\right)$.

Here, $\alpha_{m}$ is (maximum) autotroph photosynthetic efficiency per unit chlorophyll under nutrientsufficient conditions, and $Q$ is microplankton nutrient content (mmol nutrient per mmol carbon). The equation is solved for maximum nutrient content, $Q_{\max }=Q_{\max , a}(1-\eta)+q_{h} \eta$, giving:

$\alpha^{B}=\frac{\alpha_{m}{ }^{X} q_{a}^{N} Q_{\max , a}(1-\eta)}{1+b} \mathrm{~d}^{-1}\left(\mu \mathrm{E} \mathrm{m}^{-2} \mathrm{~s}^{-1}\right)^{-1}$.

The term $q_{h}$ referring to (constant) microheterotroph nutrient element:carbon ratio, disappears from the equation. $Q_{\max , a}$ is the maximum cellular content of the nutrient element, relative to carbon, in phytoplankton.

The value of the compensation irradiance must take account of respiration losses by 
microheterotrophs, and thus:

$$
\begin{aligned}
I_{c} & =\frac{r_{0}}{\alpha^{B}} \\
& =\frac{\left(r_{0 a}(1-\eta)+r_{0 h} \eta\left(1+b_{a}\right)\right)}{\alpha^{B}} \mu \mathrm{E} \mathrm{m}^{-2} \mathrm{~s}^{-1},
\end{aligned}
$$

where the $r_{0}$ terms refer to basal respiration (at zero growth) and the $b$ term gives the rate of increase of respiration rate with growth. Subscripts $a$ and $h$ refer, respectively, to autotrophs and heterotrophs. See Tett (1998) and Tett et al. (2002).

One set of (biological) loss terms is thus built into the CSTT model, and depends in particular on the value chosen for the heterotroph fraction $\eta$. The default value given in Table 5 is for typical coastal microplankton in summer, but can be improved by microscopic analysis to give the abundance and size of the microplankton flora and fauna. The other set of losses is imposed explicitly, through the external loss rate $L$ in Eq. (5). This rate is defined as the instantaneous probability, expressed as a daily rate, that any microplankter will be eaten by multicellular planktonic or benthic animals, or will sink from the euphotic zone. The consumers are assumed to be unselective filter feeders, unable to distinguish between any component of the microplankton. Typical summer rates are of order $10^{-1} \mathrm{~d}^{-1}$ (e.g. Tett and Walne, 1995) but CSTT (1994, 1997) suggested that $L$ should be taken as zero in the absence of local data on grazers.

\subsection{The yield of chlorophyll from nutrient}

In a closed system, such as an algal batch culture, the uptake of limiting nutrient $S$ from the water leads to the formation of new algal cells and hence an increase in chlorophyll $(X)$. Thus,

$q=-\frac{\Delta X}{\Delta S} \mathrm{mg} \operatorname{chl}$ (mmol nutrient $)^{-1}$.

Of course, the rate of synthesis of new chlorophyll depends on conditions, such as illumination and the supply of substances that might be limiting for chlorophyll formation rather than for biomass increase. Given constancy of such conditions, the yield $q$ might be expected to be a constant. Its value can be estimated from studies using algal cultures (Caperon and Meyer, 1972; Tett et al., 1985; Zehr et al., 1988; Sakshaug et al., 1989; Sosik and Mitchell, 1991; Levasseur et al., 1993; Sosik and Mitchell, 1994). Such studies report a wide range of values of the ratio of chlorophyll to nitrogen without any clear overall pattern in relation to cell size, growth rate or irradiance (below $300 \mu \mathrm{E} \mathrm{m}^{-2} \mathrm{~s}^{-1}$ ). Ignoring a few values of more than $7 \mathrm{mg} \mathrm{chl}(\mathrm{mmol} \mathrm{N})^{-1}$, the median of 128 values from the cited works was $2.2 \mathrm{mg} \mathrm{chl}(\mathrm{mmol} \mathrm{N})^{-1}$, with quartile values of 0.9 and $3.1 \mathrm{mg}$ chl $(\mathrm{mmol} \mathrm{N})^{-1}$. The pigment data were obtained by 'standard' spectrophotometric or fluorometric methods, and thus overestimate chlorophyll $a$ determined by precise chromatographic methods (Gowen et al., 1983; Mantoura et al., 1997). Nevertheless, they are appropriate for a model intended for comparison with observations made by the same 'standard' methods.

Eq. (14) can also be used to estimate yield in the case of the mixture of algae and microheterotrophs found in natural microplankton. Gowen et al. (1992) re-examined data for a microcosm experiment carried out by Jones et al. (1978) and estimated yields of $2.1-3.0 \mathrm{mg} \mathrm{chl}(\mathrm{mmol} \mathrm{N})^{-1}$. More recent studies in microcosms reported by Edwards (2001) and Edwards et al. (this vol.) found consistent patterns, in which initial high yields averaging $1.8 \mathrm{mg} \mathrm{chl}(\mathrm{mmol} \mathrm{N})^{-1}$ were followed by lower values centering on $1.1 \mathrm{mg} \mathrm{chl}(\mathrm{mmol} \mathrm{N})^{-1}$. The decrease may have been due to physiological changes in the algae (changing $\mathrm{x}_{q_{a}^{N}}$ ) or to diversion of nitrogen from algae to dissolved organic matter, bacteria, or protozoa. In the second case, and ignoring possible DON formation,

$q={ }^{X} q_{a}^{N}\left(1+\left(q_{h} \eta / Q_{a}(1-\eta)\right)\right)^{-1} \mathrm{mg} \operatorname{chl}(\mathrm{mmol} \mathrm{N})^{-1}$.

In the sea, nitrogen might also be diverted into animals or detritus. In all cases, $q \leqslant{ }^{X} q_{a}^{N}$.

Although Hecky and Kilham (1988) pointed out the difficulty of establishing clear relationships between nutrient loading and biomass, Gowen et al. (1992) were able to find chlorophyll-DAIN relationships in 38 out of 60 data sets examined for Scottish west coastal waters, and these regressions 
Table 5

Variables and parameter values for the CSTT model

\begin{tabular}{|c|c|c|c|}
\hline Symbol & & Value & Units \\
\hline $\begin{array}{l}S_{e q} \\
X_{\max } \\
\mu(I)\end{array}$ & $\begin{array}{l}\text { Model variables } \\
\text { Equilibrium nutrient concentration }=S_{0}+\left(s_{i} /(E V)\right) \\
\text { Potential maximum chlorophyll concentration }=X_{0}+q S_{e q} \\
\text { Microplankton relative growth rate as a function of PAR }=\alpha^{B}\left(I-I_{c}\right) \text {, applied } \\
\text { to mixed layer PAR } \overline{\bar{I}}\end{array}$ & & $\begin{array}{l}\mu \mathrm{M} \\
\mathrm{mg} \mathrm{m} \mathrm{m}^{-3}\end{array}$ \\
\hline & Site-specific parameters & & \\
\hline$E$ & Exchange rate between RRE and the sea & & $\mathrm{d}^{-1}$ \\
\hline$L$ & $\begin{array}{l}\text { Loss rate of microplankton due to mesozooplankton and benthic grazing, } \\
\text { sinking, etc. (default value) }\end{array}$ & 0.1 & $d^{-1}$ \\
\hline$s_{i}$ & Total of nutrient input to the RRE from all sources except the sea & & $\mathrm{kmol} \mathrm{d}^{-1}$ \\
\hline$S_{0}$ & Seawater ('background') nutrient concentration & & $\mu \mathrm{M}$ \\
\hline$V$ & Volume of RRE or of upper layer of RRE & & $10^{6} \mathrm{~m}^{3}$ \\
\hline$X_{0}$ & Seawater ('background') chlorophyll concentration & & $\mathrm{mg} \mathrm{m}^{-3}$ \\
\hline$q$ & $\begin{array}{l}\text { Standard parameters } \\
\text { Chlorophyll yield (from nitrogen) } \\
\text { Chlorophyll yield (from phosphorus) }\end{array}$ & $\begin{array}{l}1.1 \\
30\end{array}$ & $\begin{array}{l}\mathrm{mg} \operatorname{chl}(\mathrm{mmol} \mathrm{N})^{-1} \\
\mathrm{mg} \operatorname{chl}(\mathrm{mmol} \mathrm{P})^{-1}\end{array}$ \\
\hline$\alpha^{B}$ & $\begin{array}{l}\text { Effective photosynthetic efficiency } \\
=\alpha_{m}{ }^{X} q_{a}^{N} Q_{\max , a}(1-\eta) /(1+b)\end{array}$ & 0.006 & 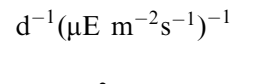 \\
\hline$I_{c}$ & $\begin{array}{l}\text { Compensation irradiance } \\
=\left(r_{0 a}(1-\eta)+r_{0, h} \eta\left(1+b_{a}\right)\right) /\left(\alpha_{m} \chi\right)\end{array}$ & 5 & $\mu \mathrm{E} \mathrm{m}^{-2} \mathrm{~s}^{-1}$ \\
\hline$\alpha_{m}$ & $\begin{array}{l}\text { Used to calculate standard parameters } \\
\text { Algal (chlorophyll-related), nutrient-replete, } \\
\text { photosynthetic efficiency }\end{array}$ & 0.042 & $\begin{array}{l}\text { mmol C (mg chl })^{-1} \\
d^{-1}\left(\mu \mathrm{E} \mathrm{m}^{-2} \mathrm{~s}^{-1}\right)^{-1}\end{array}$ \\
\hline$b$ & $\begin{array}{l}\text { Rate of increase of (microplankton) respiration with } \\
\text { growth }=b_{a}\left(1+b_{h} \eta\right)+b_{h} \eta\end{array}$ & 1.4 & \\
\hline$b_{a}$ & Rate of increase of (autotroph) respiration with growth & 0.5 & \\
\hline$b_{h}$ & Rate of increase of (heterotroph) respiration with growth & 1.5 & \\
\hline$\eta$ & $\begin{array}{l}\text { 'Heterotroph' fraction }=\text { (microheterotroph carbon } \\
\text { biomass)/(total microplankton biomass) }\end{array}$ & 0.4 & \\
\hline$Q_{\max , a}$ & Maximum autotroph nitrogen content & 0.20 & mmol $\mathrm{N}(\mathrm{mmol} \mathrm{C})^{-1}$ \\
\hline${ }^{X} q_{a}^{N}$ & Autotroph chlorophyll:nitrogen ratio & 3.0 & $\mathrm{mg} \operatorname{chl}(\mathrm{mmol} \mathrm{N})^{-1}$ \\
\hline$r_{0, a}$ & Autotroph basal respiration (at zero growth) & 0.05 & $\mathrm{~d}^{-1}$ \\
\hline$r_{0, h}$ & Heterotroph basal respiration (at zero growth) & 0.07 & $\mathrm{~d}^{-1}$ \\
\hline$\overline{\bar{I}}$ & $\begin{array}{l}\text { Submarine optics } \\
\text { 24-hr mean PAR (m mixed layer })=\left(1-m_{0}\right) m_{1} m_{2} \overline{\bar{I}}_{0}\left(\frac{1-\mathrm{e}^{-K_{\mathrm{d}} h}}{K_{\mathrm{d}} h}\right)\end{array}$ & & 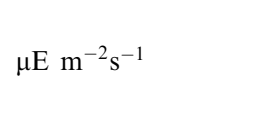 \\
\hline $\bar{I}_{0}$ & Typical summer sea-surface 24 -hr mean solar radiation & & $\mathrm{W} \mathrm{m} \mathrm{m}^{-2}$ \\
\hline$m_{0}$ & Sea albedo & 0.06 & \\
\hline$m_{1}$ & Conversion from total solar energy to PAR photons & $0.46 \times 4.15$ & $\mu \mathrm{E} \mathbf{J}^{-1}$ \\
\hline$m_{2}$ & Fraction of surface PAR that is penetrating light & 0.37 & \\
\hline$h$ & Thickness of mixed layer & & $\mathrm{m}$ \\
\hline$K_{\mathrm{d}}$ & $\begin{array}{l}\text { Diffuse attenuation for PAR at chlorophyll EQS } \\
K_{d, w}+\mu_{c}^{-1} a_{P H}^{*} X_{E Q S}\end{array}$ & & $\mathrm{~m}^{-1}$ \\
\hline$K_{d, w}$ & Local diffuse attenuation without phytoplankton & & $\mathrm{m}^{-1}$ \\
\hline$\mu_{c}$ & Mean cosine of downwelling photons & 0.85 & \\
\hline$a_{P H}^{*}$ & Absorption cross-section of coastal phytoplankton & 0.016 & $\mathrm{~m}^{2}(\mathrm{mg} \mathrm{chl})^{-1}$ \\
\hline$X_{E Q S}$ & Chlorophyll concentration at threshold for eutrophic conditions & 10 & $\mathrm{mg} \mathrm{chl} \mathrm{\textrm {m } ^ { - 3 }}$ \\
\hline
\end{tabular}


Table 6

Data for the CSTT model for the OAERRE sites

\begin{tabular}{|c|c|c|c|c|c|c|}
\hline & $\begin{array}{l}\text { Kongs- } \\
\text { fjorden }\end{array}$ & $\begin{array}{l}\text { Gull- } \\
\text { maren }\end{array}$ & $\begin{array}{l}\text { Himmerfjärden } \\
\text { (a), (b) }\end{array}$ & $\begin{array}{l}\text { Firth of Clyde } \\
\text { (a), (b) }\end{array}$ & $\begin{array}{l}\text { Golfe de } \\
\text { Fos }\end{array}$ & $\begin{array}{l}\text { Ria } \\
\text { Formosa }\end{array}$ \\
\hline$V\left(10^{6} \mathrm{~m}^{3}\right)$ & 4580 & 765 & 1900,633 & 31800,3130 & 336 & 88 \\
\hline$E\left(\mathrm{~d}^{-1}\right)$ & 0.1 & 0.10 & $0.025,0.025$ & $0.05,0.14$ & 0.05 & 2.1 \\
\hline$s_{i}(\mathrm{~N})\left(\mathrm{kmol} \mathrm{d}^{-1}\right)$ & 0.5 & 157 & $100^{\mathrm{a}}, 266$ & $1423^{\mathrm{a}}, 1747$ & 21.5 & 84.3 \\
\hline$s_{i}(\mathrm{P})\left(\mathrm{kmol} \mathrm{d}^{-1}\right)$ & 0.05 & 2.36 & $1.77^{\mathrm{a}}, 3.54$ & $136^{\mathrm{a}}, 168$ & 1.24 & 1.86 \\
\hline$S_{0}(\mathrm{~N})(\mu \mathrm{M})$ & 2.5 & 0.02 & $0.1,0.1$ & $0.5,1.0$ & 0.05 & 0.05 \\
\hline$S_{0}(\mathrm{P})(\mu \mathrm{M})$ & 0.5 & 0.02 & $0.05,0.05$ & $0.1,0.2$ & 0.05 & 0.05 \\
\hline$X_{0}\left(\mathrm{mg} \mathrm{chl} \mathrm{m}^{-3}\right)$ & 1 & 4 & 2,4 & 1,2 & 0.1 & 0 \\
\hline cloud fraction & 0.6 & 0.5 & 0.5 & 0.6 & 0.2 & 0.3 \\
\hline 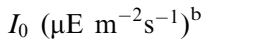 & 410 & 490 & 530 & 500 & 680 & 650 \\
\hline$K_{d, w}\left(\mathrm{~m}^{-1}\right)$ & 0.08 & 0.12 & $0.12,0.15$ & $0.15,0.30$ & 0.05 & 0.50 \\
\hline$K_{\mathrm{d}}$ at $\operatorname{EQS}\left(\mathrm{m}^{-1}\right)$ & 0.27 & 0.31 & $0.31,0.34$ & $0.34,0.49$ & 0.24 & 0.69 \\
\hline$h(\mathrm{~m})$ & 20 & 15 & 15,10 & 20,20 & 8 & 1.5 \\
\hline$I\left(\mu \mathrm{E} \mathrm{m}{ }^{-2} \mathrm{~s}^{-1}\right)$ & 30.9 & 42.4 & $45.9,62.7$ & $29.6,20.5$ & 121.5 & 162.2 \\
\hline$S_{e q}(\mathrm{~N})(\mu \mathrm{M})$ & 2.5 & 2.1 & $7.8,16.9$ & $2.5,5.0$ & 1.3 & 0.5 \\
\hline$S_{e q}(\mathrm{P})(\mu \mathrm{M})$ & 0.50 & 0.05 & $0.16,0.27$ & $0.29,0.58$ & 0.12 & 0.06 \\
\hline$X_{m}(\mathrm{~N})\left(\mathrm{mg} \mathrm{chl} \mathrm{m}^{-3}\right)$ & 3.8 & 6.3 & $10.6,22.6$ & $3.7,7.5$ & 1.6 & 0.6 \\
\hline$X_{m}(\mathrm{P})\left(\mathrm{mg} \mathrm{chl} \mathrm{m}^{-3}\right)$ & 16.0 & 5.5 & $6.8,12.2$ & $9.7,19.5$ & 3.8 & 1.8 \\
\hline$\mu(I)\left(\mathrm{d}^{-1}\right)$ & 0.16 & 0.22 & $0.25,0.35$ & $0.15,0.09$ & 0.70 & 0.94 \\
\hline$\mu(I) /(L+E)$ & 0.78 & 1.12 & $1.96,2.77$ & $0.98,0.39$ & 4.66 & 0.43 \\
\hline Eq N:P & 5 & 41 & 48,62 & 9,9 & 11 & 8 \\
\hline $\mathrm{N}: \mathrm{ECE} / S_{e q}$ & 0.0 & 1.0 & $1.0,1.0$ & $0.8,0.8$ & 1.0 & 0.9 \\
\hline $\mathrm{P}: \mathrm{ECE} / S_{e q}$ & 0.0 & 0.6 & $0.7,0.8$ & $0.7,0.7$ & 0.6 & 0.2 \\
\hline
\end{tabular}

Bold shows limiting nutrient. Himmerfjärden: (a) (outer) basin 1 (Svärdsfjärden); (b) proper (basins $2+3$ ) + basin 4 . Firth of Clyde: (a) Arran Deep, or main, basin; (b) Inner Firth.

${ }^{a}$ In these cases, the outer basin is deemed to receive all nutrients input to the inner basin, plus the given inputs to the outer basin.

${ }^{\mathrm{b}}$ As given here, $I_{0}$ has been calculated from surface irradiance by taking account of albedo and the conversion from Joules to PAR photons.

gave a median yield of $1.05 \mathrm{mg} \mathrm{chl}(\mathrm{mmol} \mathrm{N})^{-1}$ (with a wide range, from 0.25 to 4.4 ). The median value was recommended by CSTT $(1994,1997)$ for use in their model, and is supported by the recent work by Edwards (2001). In the case of the Himmer fjord, Larsson and Kratzer (2002) report a relationship (Fig. 3a) between maximum spring chlorophyll concentration and maximum DAIN before the spring bloom. Although the best fit was found with log-transformed variables, the slope of the $\log -\log$ plot was close to 1 , and re-interpreting the data suggests a $q$ value of about $0.8 \mathrm{mg} \operatorname{chl}(\mathrm{mmol} \mathrm{N})^{-1}$.

In the case of fresh-waters, which mostly flush rather slowly compared with salt waters of similar size, relationships between biomass and nutrient loading are well established. For example, studies of the Canadian experimental lakes (Schindler, 1977) resulted in a relationship between mean annual chlorophyll concentration and mean annual total phosphorus, with a slope equivalent to about $30 \mathrm{mg}$ chl $(\mathrm{mmol} \mathrm{P})^{-1}$.

In applying the CSTT model to OAERRE sites we have used the CSTT value of $1.1 \mathrm{mg} \mathrm{chl}(\mathrm{mmol} \mathrm{DAIN})^{-1}$ for nitrogen, and a value of $30 \mathrm{mg} \mathrm{chl}(\mathrm{mmol} \mathrm{DAIP})^{-1}$ for phosphorus. It may be remarked that these yields imply a phytoplankton or microplankton atomic $\mathrm{N}: \mathrm{P}$ ratio of $29: 1$, higher than the Redfield ratio of 16:1. However, the nitrogen and phosphorus yields are not simultaneous, but apply each to the case of limitation by the appropriate nutrient. Following a 
'threshold-limitation, internal nutrient' model (Droop, 1983) suggests that the ratios of the $\mathrm{N}$ and $\mathrm{P}$ yields should be somewhere between the Redfield ratio and the ratio of the subsistence quota' for each nutrient. The latter is at least 30:1 (Tett et al., in press).

\subsection{Sources and sinks of nutrients}

The CSTT model distinguishes nutrients in the sea water outside the RRE, and described by the concentration $S_{0}$, from inputs of nutrients from local point sources, land drainage, and the atmosphere, summarised by the flux term $s_{i}$. Although changes in silicate availability may influence the ratio of diatoms to other phytoplankton (Officer and Ryther, 1980; Justic et al., 1995), we deal here only with nitrogen and phosphorus and the limitation of bulk biomass during summer. The potential hypernutrifying effect of local nutrients was estimated by the Equilibrium Concentration Enhancement, $\mathrm{ECE}=s_{i} /(E \cdot V)$, and the contribution relative to sea-derived nutrients (Table 6) was estimated from the ratio of ECE to $S_{e q}$.

In one case this ratio is low for both nitrogen and phosphorus. The input of terrestrial and atmospheric nutrients into Kongsfjorden is poorly known, but is probably low, with most nutrients coming from the waters of the Greenland Sea or local recycling in deeper water. In all other cases the local inputs from land and atmosphere provided almost all nitrogen, and between $20 \%$ and $80 \%$ of phosphorus.

In the case of the three sites exchanging with shelf seas, their source water is enriched by anthropogenic nutrients, but summer concentrations are typically depleted due to phytoplankton growth. This is certainly true of the Baltic Sea (Wulff et al., 1994), providing the boundary condition for the Himmer fjord. Gullmaren source waters originate in the Baltic, by way of the Belt Sea and Kattegat, and in the southern North Sea, by way of the Skagerrak. All these source waters are richer in nutrients than they were 40 years ago, but the rate of increase of $\mathrm{N}$ loading seems to have levelled off, and $\mathrm{P}$ loadings are now decreasing (Hansen et al., 2001). The North Channel of the Irish Sea provides the source water for the Firth of
Clyde (Grantham and Tett, 1993), but there is some dispute about Irish Sea enrichment (Allen et al., 1998; Le Gall et al., 2000; Gowen et al., 2002). It may be that undisputed riverine discharges of anthropogenic $\mathrm{N}$ and $\mathrm{P}$ are offset by increased denitrification and burial.

In the case of the Firth of Clyde, river input is enriched by nutrients leached from soil, agricultural wastes, and urban waste water (Haig, 1986). In the Himmer fjord, the direct discharge of urban waste water is of great importance; the authorities operating the waste water plant have experimented with tertiary treatments giving a range of values of the N:P ratio in discharged water (Elmgren, 1997). The small rivers draining into the Himmer fjord contribute about the same amount of nutrients as the treatment plant; they are more enriched with phosphorus than with nitrogen. The main terrestrial source of nutrient input to the Gullmar fjord is discharge of the river Örekil, with a little additional industrial and domestic waste.

The Gulf of Fos draws its sea water supply from the surface layer of the oligotrophic Mediterranean. A small part of the nutrient-enhanced Rhône river discharge reaches the bay through a canal (Arfi, 1984). Nutrient concentrations in the Ria Formosa in winter are controlled by the Atlantic tidal inflow and agricultural runoff, whereas, in summer, sediment remineralisation and sewage are the main controls (Newton et al., 2003).

At least some of these RREs provide local sinks for nutrients by way of denitrification, and burial of phosphate adsorbed to sediment particles. Larsson and Engqvist (1997) suggested that on average $55 \%$ of local input of available nitrogen was lost as a result of sediment denitrification in the Himmer fjord. Whereas this nitrogen will have passed though euphotic zone primary producers before arriving at the sea-bed, and so cannot be subtracted from $s_{i}$ in Eq. (3), it nevertheless represents a loss of long-term potential for trophic stimulation. Rates of denitrification in coastal marine and estuarine sediments are highly variable (Seitzinger, 1988). Larsson and Engqvist (1997) showed a weak correlation between annual denitrification and the total annual nitrogen loading in the inner basin of Himmerfjärden. Erlandsson and 
Arneborg (2002) review data showing more denitrification in Gullmar sediment beneath a $70 \mathrm{~m}$ water column than in a sediment at $115 \mathrm{~m}$. Nutrient flux studies in the Gulf of Fos (Grenz, 2002) showed nitrate uptake by the sediment on most occasions. This was due both to assimilation by microphytobenthos and to sediment denitrification. On most occasions the Fos sediments released ammonium into the water at the same time as they consumed nitrate, as reported also for the Himmer fjord (Blomqvist and Larsson, 1997).

The nutrient concentrations $S_{0}$ given in Table 6 are for the superficial layer of the sea at the entrance to the system. This may underestimate the marine input in cases where there is inflow of more nutrient-rich water at an intermediate depth, which then entrains into near-surface water. A final problem concerns the forms of nutrients to be included in this inflow. The CSTT model deals with available nutrients, and so should also take account of organic compounds that mineralise easily. However, in Table 6 we have used only data for inorganic forms of the nutrients.

\subsection{Irradiance}

Mean photosynthetically available radiation (PAR, 400-750 nm) in a vertically mixed layer of thickness $h$ can be approximated by

$$
\begin{aligned}
\overline{\bar{I}} & =\left(1-m_{0}\right) m_{1} m_{2} I_{0} \frac{1-\mathrm{e}^{-K_{d} h}}{K_{d} h} \\
& \cong \frac{m I_{0}}{K_{d} h} \mu \mathrm{Em}^{-2} \mathrm{~s}^{-1}
\end{aligned}
$$

where $I_{0}$ is 24-h mean solar radiation (all wavelengths) at ground level, in $\mathrm{W} \mathrm{m}^{-2}$, the factor $m_{0}$ is sea-surface albedo, $m_{1}$ converts solar radiation to PAR photons and $m_{2}$ deals with losses additional to those of Beer-Lambert decay. Apart from $h$, the crucial local property is the PAR diffuse attenuation coefficient $K_{d}$, which is made up of components due to sea water itself, coloured dissolved organic matter (CDOM), also referred to as yellow substance, phytoplankton pigments, other organic particulates, and inorganic particulates.

In 'optical case I' waters (Prieur and Sathyendranath, 1981) optical properties are dominated by phytoplankton pigments. Such waters are often thought of as being restricted to those of the oceans, distant from freshwater inputs of yellow substance and tidal resuspension of particles. However, many eutrophic waters can be treated as case I when phytoplankters are either the largest, or the most variable, optical component. Concentrations of CDOM and suspended particulates, although large, are often relatively constant in areas of restricted exchange. It is this that allows Secchi depth, related approximately to diffuse attenuation by

$z_{S}=f_{S} / K_{d}$

to serve as a measure of eutrophication (Sanden and Håkansson, 1996). Larsson and Kratzer (2002) demonstrate a good inverse correlation between total chlorophyll and Secchi depth in Himmerfjärden, leading to the inverse relationship between Secchi depth and total nitrogen shown in Fig. 3(c). The factor $f_{S}$ in Eq. (17) is about 1.7 in clear marine waters (Raymont, 1980), falling to about 1.4 in turbid coastal waters with high suspended sediment load (Holmes, 1970) and increasing to higher values (1.84) in the lowsalinity waters of the Baltic Sea (Edler, 1997).

The submarine optical data (Table 6) needed to estimate typical values of $\overline{\bar{I}}$ for use in the CSTT model were obtained in several ways. Some are based on estimates of $K_{d}$ from radiometer measurements of underwater light, others on Secchi depth. All have been corrected to the EQS chlorophyll concentration of $10 \mathrm{mg} \mathrm{m}^{-3}$ using

$K_{d}=K_{d, w}+\mu_{c}^{-1} a_{\mathrm{PH}}^{*} X_{\mathrm{EQS}}$.

The term $K_{d, w}$ specifies the diffuse attenuation coefficient measured in the absence of phytoplankton but with all other light-attenuators present. It is treated as a site-specific parameter. Taking account of the EQS for chlorophyll is necessary because the comparison of Eq. (5) involves microplankton growth rate under conditions of high biomass. The parameter $a_{\mathrm{PH}}^{*}$ is the absorption cross-section of photosynthetic pigments, with a value of $0.016 \mathrm{~m}^{2} \mathrm{mg} \mathrm{chl}^{-1}$ in coastal waters (Tett, 1990). The equation uses $\mu_{c}$, the mean cosine (the average angle relative to the vertical of the submarine photon flux), to convert absorption to attenuation. 
Fjords often act as settlement tanks, and so the optical contribution of particulates, other than those associated with phytoplankton, tends to be low. Yellow substance, however, is often important, as it is in the Firth of Clyde (Bowers et al., 2000), which receives large discharges from rivers draining peaty, acid, land. Here, the yellow substance concentration is inversely correlated to salinity. In the Baltic Sea light absorption is dominated by yellow substance (Kratzer, 2000). As the surface layer salinity of the Himmer fjord is only about 0.5 lower than the 6-7 of the open Baltic Sea (Larsson and Kratzer, 2002), similar optical conditions, i.e. the optical dominance of yellow substance may be expected. In the Ria Formosa, resuspended particulates tend to dominate light absorption due to the strong tidal flows. Glacier melt in Kongsfjorden releases many fine particles which can increase water turbidity in the inner parts of the fjord (Svendsen et al., 2002). Secchi depth in the outer fjord can, however, exceed $20 \mathrm{~m}$. Water in the Golfe de Fos alternates between high transparency when wind strength is low and high turbidity, when wind-induced waves resuspend particles from the sea-bed (Tett and Grenz, 1994). The greatest risk of algal blooms occurs during periods of calm weather, and the absorption of light by inorganic suspended matter has thus been ignored in the case of Fos gulf.

Finally, the sea-surface solar irradiance values in Table 6 were either obtained from local observations or were calculated from latitude, time of year and mean cloud cover, using an algorithm based on that of the COHERENS model (Luyten et al., 1999).

\subsection{Results of the CSTT model}

Site-specific data for the simple model are included in Table 6, and standard parameter values needed for its use are listed in Table 5. In the case of stratified systems, the given values are those for a superficial layer with thickness shown by the value of $h$. For example, in the case of Gullmaren, this layer was equated with the Kattegat water, and taken to be $15 \mathrm{~m}$.

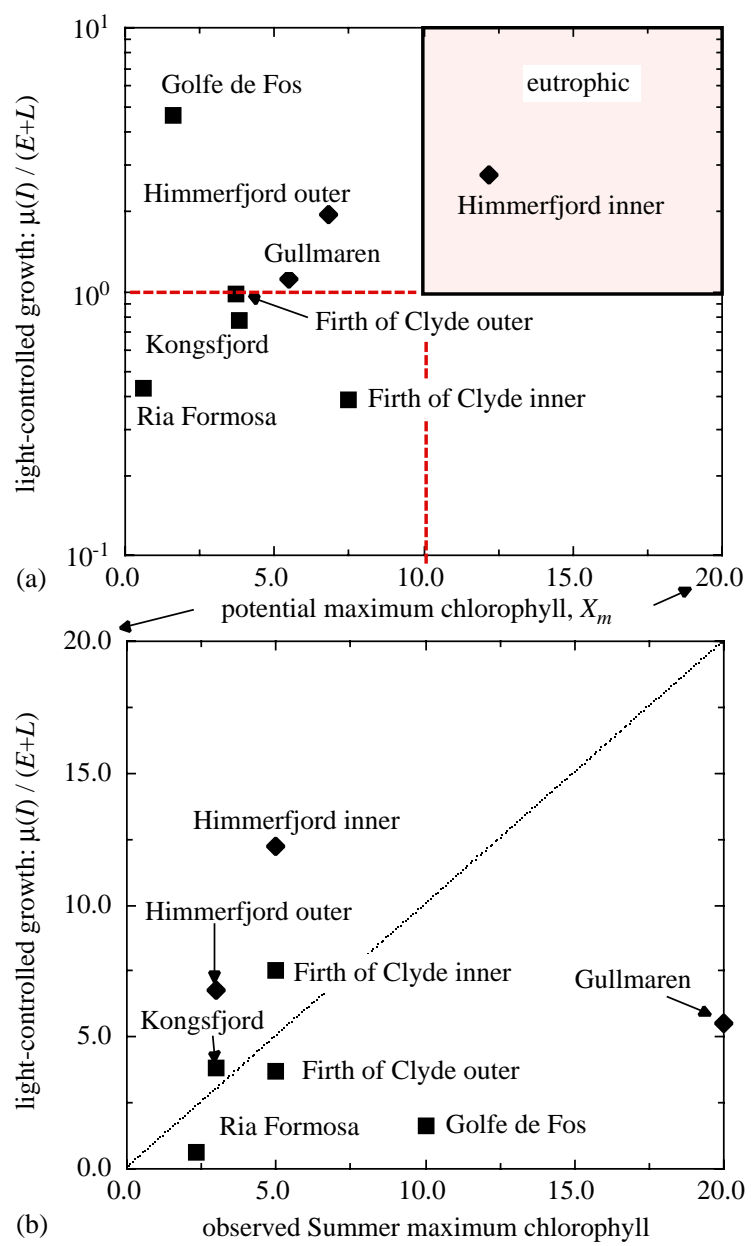

Fig. 6. Results of the CSTT model for the OAERRE sites. (a) plotted in growth-rate and maximum chlorophyll variable space; (b) plot of predicted versus observed summer maximum chlorophyll. N-limited sites shown by filled squares, P-limited sites shown by filled diamonds.

Results are shown in Fig. 6(a), in which the axes are predicted maximum chlorophyll and the estimated ratio of growth rate to losses. The 'potentially eutrophic' region is drawn from the CSTT EQS of $10 \mathrm{mg} \mathrm{chl} \mathrm{m}^{-3}$ and the ratio $\mu(\overline{\bar{I}}) /(E+L)=1$, derived from the condition of Eq. (5) and using $0.1 \mathrm{~d}^{-1}$ for $L$ in all cases. Only one of the sites falls into the 'eutrophic' region, and that is the inner part of the Himmer fjord, which is shown as potentially phosphorus-limited. Gullmaren may also be potentially P-limited. All 
the other sites are nitrogen-limited, in that $X_{\max }$ predicted from DAIN is less than that predicted from DAIP.

The CSTT model diagnoses the inner basins of the Himmer fjord as potentially eutrophic despite a comparatively low nutrient loading relative to their volume. The ratio $S_{i} / V$ for Himmerfjärden basins $2-4$ is less, for both $\mathrm{N}$ and $\mathrm{P}$, than the values for the inner Firth of Clyde and the Ria Formosa. The diagnosis of potentially high maximum chlorophyll results in particular from the slow flushing rate of the Himmer fjord $\left(0.025 \mathrm{~d}^{-1}\right)$ compared with that of the inner Firth of Clyde $\left(0.14 \mathrm{~d}^{-1}\right)$ and the Ria Formosa $\left(2.1 \mathrm{~d}^{-1}\right)$. In reality, greatest summer chlorophyll concentrations in Himmerfjärden $\left(5 \mathrm{mg} \mathrm{chl} \mathrm{m}^{-3}\right)$ do not reach the potential maximum or exceed the EQS, so losses could be greater than the conservative value of $0.1 \mathrm{~d}^{-1}$ that has been used in the CSTT calculations. Additionally, some nutrients discharged by the sewage treatment plant may be trapped below the summer pycnocline.

Fig. 6(a) is the result of using the CSTT model. Fig. 6(b) evaluates the model by comparing the predicted values of $X_{\max }$ with observed summer maxima of chlorophyll. If the model is valid and its parameter values are correct, the points should fall on or to the left of the diagonal line, because the model is expected to predict the worst case that might occur. The chlorophyll predictions for Kongsfjorden, Himmerfjärden and the inner Firth of Clyde are indeed greater than the maximum chlorophyll observed during summer. The discrepancy in the case of the outer Firth of Clyde is relatively small and will be disregarded in this section, although we will deal with the Firth at length in the next section. This leaves three discrepant cases to consider.

In the case of the Ria Formosa, the observed maximum value is about twice the predicted maximum, but both predicted and observed maximum chlorophyll are low. The discrepancy may lie in the application of a box model to a heterogeneous system in which the contents of the inner parts of the low-water channels remain within the Ria for longer than implied by the bulk residence time of less than a day.
The real values for Fos gulf and Gullmaren are much greater than the predicted values, and would themselves place these sites in the eutrophic

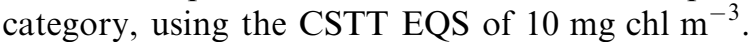
In the case of Gullmaren the explanation may be that the maximum of the observed time-series is biased by data from 1987 to 1988 , when there were summer blooms in the Kattegat (Lindahl, 1994). The value of $X_{0}$ of $4 \mathrm{mg} \mathrm{chl} \mathrm{m}{ }^{-3}$ did not take account of such a case. In the case of the Gulf of Fos, the explanation may well involve circulation patterns inside the gulf. High resolution numerical simulations (Ulses, 2002) suggest that under some wind conditions, the inner part of the Gulf, containing less than a third $(29 \%)$ of the total volume, may be largely isolated from the outer part. If such conditions were combined with haline stratification in the inner part, the volume of water receiving nutrients from the Rhône canal would have been much less than assumed in Table 6, and the resulting estimates of the ECE of nutrients and the maximum chlorophyll would have been much greater.

\section{Trophic state control investigated with a dynamic model}

The CSTT model is intentionally impoverished in number of state variables and parameters. This section shows results from a more detailed model (Lee, 2002) that combines a 2-microplankton biological model (Lee et al., 2002) with a multiple compartment model of the Firth of Clyde (Fig. 7). The biological model has four compartments, for diatom-dominated microplankton, flagellatedominated microplankton, slow-decaying detritus, and fast-sinking phytodetritus. The model cycles nitrogen and silicon and produces and consumes carbon biomass. In addition to this greater biogeochemical complexity, compared with the Riley + model of Eqs. (1) and (2), each of these compartments has additional state variables, $Q$, each representing the atomic ratio of a nutrient element to organic carbon.

The introduction of these nutrient quota variables allows the growth rate of each microplankton to be calculated by a modification of the 

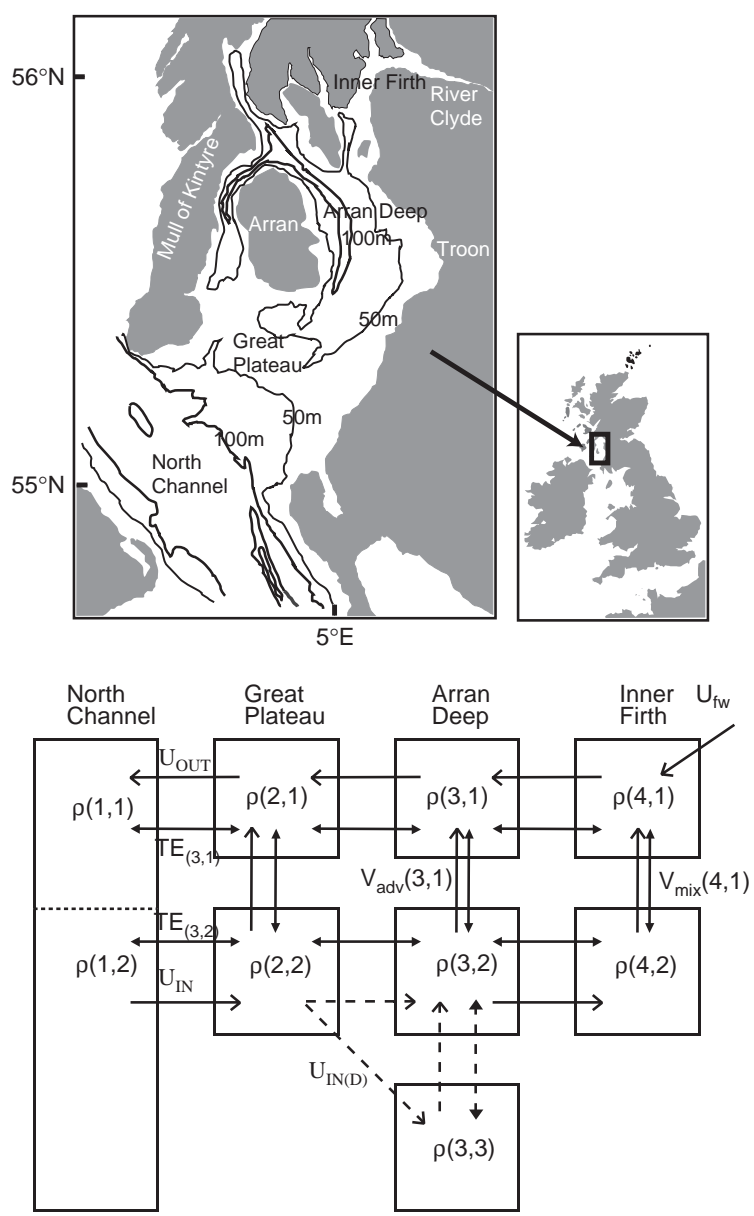

Fig. 7. The Firth of Clyde - map and model compartmentalisation.

'cell-quota, threshold limitation' model of Droop (1983):

$\mu=\min \left\{f(\overline{\bar{I}}), f(Q),\left[f\left({ }^{\mathrm{Si}} Q\right)\right]\right\} \mathrm{d}^{-1}$

$f(\overline{\bar{I}})=\frac{\alpha^{B} \overline{\bar{I}} \chi-r_{0}}{1+b}, \quad$ where $\chi={ }^{X} q_{a}^{N}\left(Q-q_{h} \eta\right)$,

$f(Q)=\mu_{\max }\left(1-\frac{Q_{\min }}{Q}\right), \quad$ where $Q=\frac{N}{B}$,

$f\left({ }^{\mathrm{Si}} Q\right)=\mu_{\max }\left(1-\frac{{ }^{\mathrm{Si}} Q_{\min }}{{ }_{\mathrm{Si}} Q}\right), \quad$ where ${ }^{\mathrm{Si}} Q=\frac{{ }^{\mathrm{Si}} N}{B}$,

where $B, N$ and ${ }^{\mathrm{Si}} N$ are the (organic) carbon, nitrogen and silicon (diatoms only) of a micro- plankton compartment. Most of the parameters in this equation are derived from algal and microheterotroph constants by equations involving the 'heterotroph fraction' $\eta$, the proportion that bacterial and protozoan biomass contributes to total microplankton carbon. The use of two microplanktons allows for a seasonal succession from a spring microplankton $(\eta=0.2)$, in which diatoms are the most important component, to a summer microbial loop community $(\eta=0.6)$. The parameter ${ }^{X} q_{a}^{N}$ was $3 \mathrm{mg} \mathrm{chl}(\mathrm{mmol} \mathrm{N})^{-1}$ for the algal component of both microplanktons, based on Tett (1998). Bulk chlorophyll yield in the model is:

$$
\begin{aligned}
q= & \frac{\left(X_{1}+X_{2}\right)}{\left(N_{1}+N_{2}\right)} \\
= & { }^{X} q_{a}^{N}\left(1-q_{h}\right. \\
& \left.\times\left(\frac{\eta_{1}(1-\psi)+\eta_{2} \psi}{Q_{1}(1-\psi)+Q_{2} \psi}\right)\right) \mathrm{mg} \mathrm{mmol}^{-1},
\end{aligned}
$$

where subscripts 1 and 2 refer respectively to the diatom-dominated and flagellate-dominated microplankton. The parameter $q_{h}$ gives the (constant) nitrogen content of pelagic microheterotrophs,

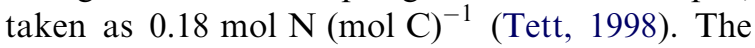
variable $\psi$ describes the relative contribution $B_{2} /\left(B_{1}+B_{2}\right)$ of flagellate-dominated to total microplankton.

In the CSTT model, the loss term $L$ is constant. In the present model, the analogous losses are variable. Firstly, algorithms for shear-induced aggregation of diatom-dominated microplankton create a sinking loss which is greatest when this microplankton is most abundant. Secondly, losses to mesozooplankton were calculated as grazing pressure derived (Tett and Walne, 1995) from climatological zooplankton data (Adams, 1986). This grazing was applied to the whole of the diatom-dominated microplankton but only to the heterotrophic part of the flagellate-dominated microplankton, on the grounds that the phytoflagellate component of the latter was too small for capture by copepods.

The physical sub-model included horizontal tidal exchange, and an estuarine circulation (Simpson and Rippeth, 1993) in which the outflow 
from an upper compartment of density $\rho$ was:

$$
U_{\text {out }}=k_{H R}\left(\rho_{0}-\rho\right) 10^{6} \mathrm{~m}^{3} \mathrm{~d}^{-1} \text {, }
$$

where $\rho_{0}$ is the density of the adjacent seawards compartment. $U_{\text {out }}$ defaulted to river input $U_{F W}$ when $\rho \geqslant \rho_{0}$. The inflow $U_{\text {out }}-U_{F W}$ to the Arran Deep region entered, and thus renewed, the 'deep' compartment (3,3 in Fig. 7) only when its density exceeded that of water already there. Vertical mixing was calculated by a 2-layer approximation of the depth-resolved model of Simpson and Rippeth (1993). The approximation conserves potential energy and takes into account internal tidal mixing (Stigebrandt, 1976; Stigebrandt and Aure, 1979) as well as superficial stirring by wind, and near-bed stirring by the barotropic tide.

Simulations were forced with river run-off for 1993-94, climatological meteorology with realistic additional high-frequency variability added as 'pseudo-weather' (Elliott and Li, 1995), and climatological outer boundary conditions. Physical and biological model parameter values were optimised using observations made during a series of cruises during 1993-94 (Jones et al., 1995; Rippeth et al., 1995; Rippeth and Jones, 1997; Midgely et al., 2001). Fig. 8 compares an optimised simulation of temperature, salinity, chlorophyll, and nitrate, with observations of these variables in the upper compartment of the Arran Deep basin of the Firth of Clyde. The simulation captures most features of the seasonal cycle quite well, although the Spring Bloom and the resulting draw-down of nitrate were perhaps underestimated relative to observations. The agreement between simulations and observations is sufficient for us to deem the model to be a reliable representation of reality, and thus to justify using it to investigate the $q$ and $E$ parameters of the CSTT model.

Fig. 9 shows the effects of removing either the grazing pressure due to mesozooplankton or the respiratory losses due to microheterotrophs. It suggests that it is the microheterotrophs that provide the strongest control on biomass; without them the yield of chlorophyll from assimilated nitrogen is higher, and simulated biomass exceeds the CSTT EQS for much of the summer. In Fig. 9(b), the simulated ratio of chlorophyll to (a) Temperature $\left({ }^{\circ} \mathrm{C}\right)$

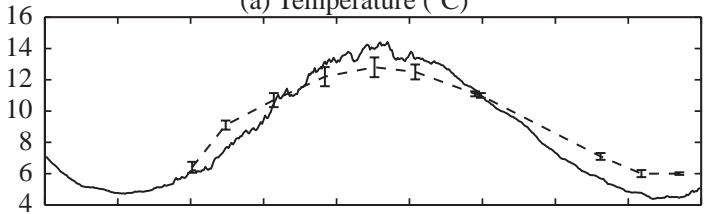

(b) Salinity (psu)

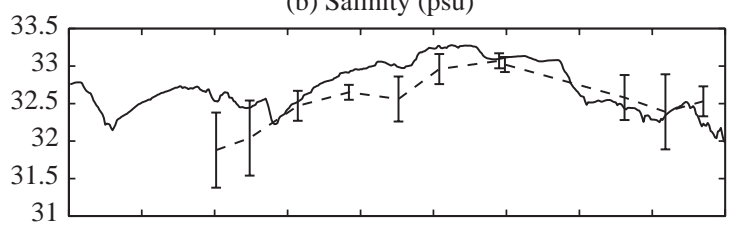

(c) Total chlorophyll $\left(\mathrm{mg} \mathrm{m}^{-3}\right)$

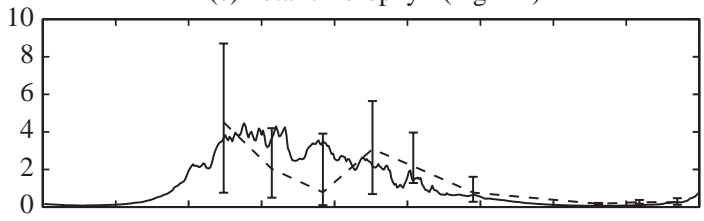

(d) Nitrate $\left(\mathrm{mmol} \mathrm{m}^{-3}\right)$

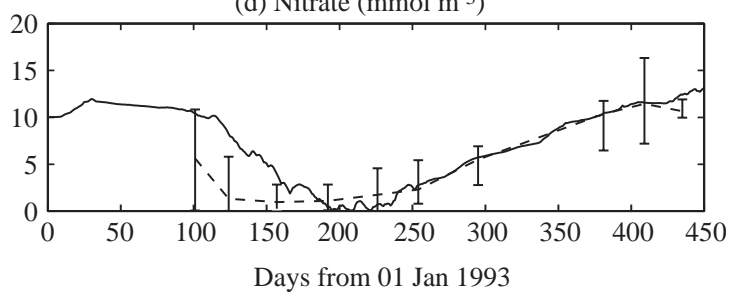

Fig. 8. Firth of Clyde model results for the upper compartment in the main basin: comparison of best simulation with observations (a) temperature, (b) salinity, (c) chlorophyll, (d) nitrate. Error bars in (a) and (b) give standard deviation of observed values during each cruise. Error bars in (c) and (d) give range.

microplankton nitrogen, specified by Eq. (21), was, in the case of the standard simulation, least in summer when the flagellate fraction $\psi$ was greatest. Implicit removal of microheterotrophs, by setting $\eta$ to zero, resulted in a higher chlorophyll yield which was, as required by Eq. (21), ${ }^{X} q_{a}^{N}$. The standard simulation resulted in summer values of $q$ which were about $1.5 \mathrm{mg} \mathrm{chl}(\mathrm{mmol} \mathrm{N})^{-1}$, and hence higher than the value of $1.1 \mathrm{mg} \mathrm{chl}(\mathrm{mmol} \mathrm{N})^{-1}$ used in the CSTT model. The higher value of $q$, if used in the CSTT model, would increase the estimate of maximum chlorophyll and so improve agreement 


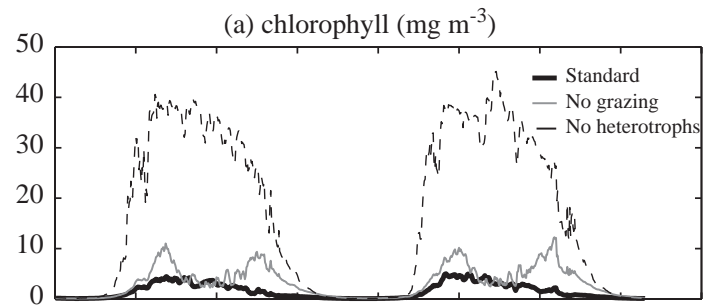

(b) bulk microplankton $\mathrm{q}$

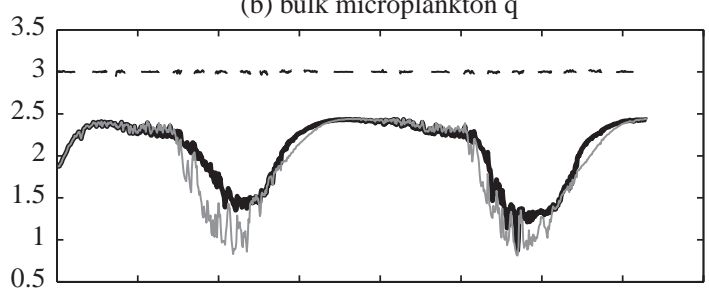

(c) ratio of chlorophyll to total system $\mathrm{N}$

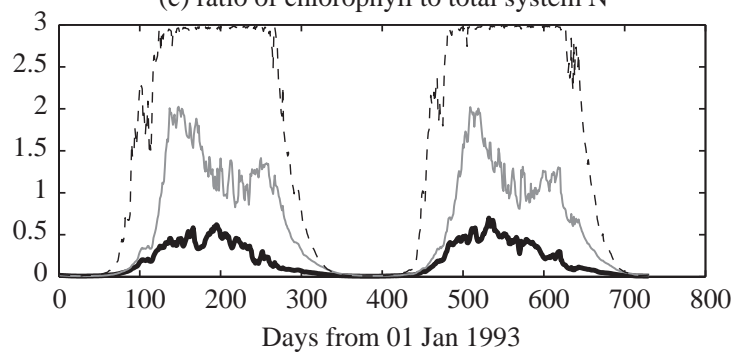

Fig. 9. Firth of Clyde model results for the upper compartment in the main basin: numerical experiments: (a) chlorophyll, (b) bulk microplankton chlorophyll yield, (c) ratio of chlorophyll to total system nitrogen. Simulations: 1. standard conditions; 2. no mesozooplankton grazing; 3. (with mesozooplankton grazing but) heterotroph fraction set to zero for both microplanktons.

between estimated and observed maximum chlorophyll in the outer basin of the Firth of Clyde, shown to be somewhat discrepant in Fig. 6.

Fig. 9(c) shows that in the standard simulation the ecosystem converted only a small part of available nitrogen into chlorophyll. During winter the nutrient remained mainly as nitrate, because lack of light restricted primary production; during summer, much of the nitrogen was contained in detritus, mesozooplankton, and deep water. Removal of grazers or microheterotrophs allowed algae to make more effective use of the nutrient.

Fig. 10 shows seasonal variation in the exchange rates of the upper compartments of the Firth of

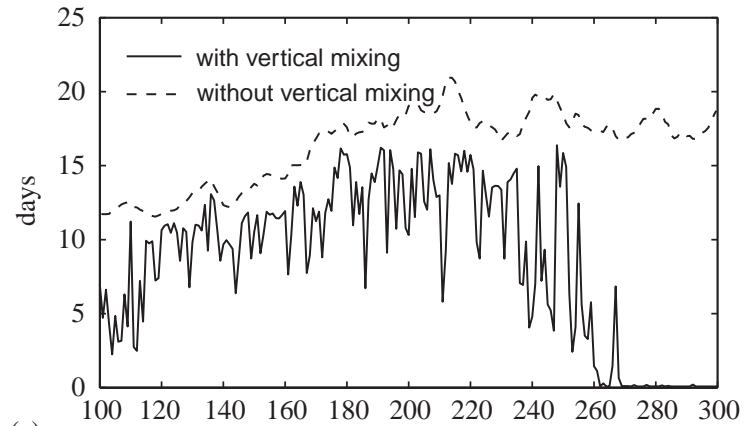

(a)

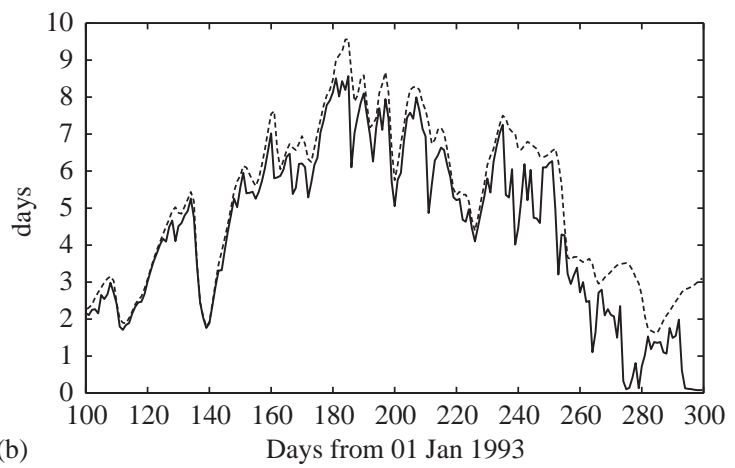

Fig. 10. Firth of Clyde model: water residence times $\left(E^{-1}\right)$ for the upper compartment of (a) the main basin, and (b) the Inner Firth, with and without the contribution of vertical mixing.

Clyde main basin (the Arran Deep) and the inner Firth. The simulation results are presented as flushing time, $E^{-1}$, and were calculated by dividing the volume of each compartment by the volume exchanged each day with adjacent compartments. Flushing time was low (exchange rate was high) during parts of the autumn and winter when the simulated upper mixed layer extended below the surface compartment of the model. Even neglecting such vertical mixing, which may in part be an artefact of the thick-layer model, the spring and summer residence times in the main basin were 15-20 days, less than the residence times of 2-4 months given by Edwards et al. (1986) and Midgely et al. (2001) for the entire basin. In the Inner Firth, vertical mixing is weaker because of stronger haline stratification, but the resulting estuarine circulation led to a summer residence time between 5 and 8 days in the upper layer 
(Fig. 10b). In both cases, the variability in exchange rates demonstrates that the use of a single value in the CSTT model is an approximation.

\section{Discussion}

\subsection{Introduction}

Cloern (2001) distinguished several phases in the evolution of ideas of coastal eutrophication. In the first phase, strongly influenced by limnology, the conceptual models focused on

changing nutrient input as a signal, and responses to that signal as increased phytoplankton biomass and primary production, decomposition of phytoplankton-derived organic matter, and enhanced depletion of oxygen from bottom waters.

The current phase tries to explain

differences in the responses of lakes and coastalestuarine ecosystems to nutrient enrichment

in terms of

system-specific attributes that act as a filter to modulate the responses to enrichment (leading to large differences among estuarine-coastal systems in their sensitivity to nutrient enrichment).

\section{It also identifies}

a complex suite of direct and indirect responses including linked changes in: water transparency, distribution of vascular plants and biomass of macroalgae, sediment biogeochemistry and nutrient cycling, nutrient ratios and their regulation of phytoplankton community composition, frequency of toxic/harmful algal blooms, habitat quality for metazoans, reproduction/growth/survival of pelagic and benthic invertebrates, and subtle changes such as shifts in the seasonality of ecosystem functions.

The next phase will concern the way in which

system-specific attributes constrain or amplify the responses of coastal ecosystems to nutrient enrichment and must also deal with wider aspects of eutrophication, including interaction with other humanderived stressors and the need to develop strategies for ecosystem rehabilitation.

OAERRE's objectives include the construction of simplified screening models for the diagnosis and prognosis of eutrophication. One aim of this paper has been to demonstrate such a model by using it to estimate the trophic status of the OAERRE sites, and to unpack its apparently simple contents by showing that its parsimonious set of parameters embodies, or requires, much knowledge of fundamental physical and biogeochemical processes in RREs. At first sight, the modified CSTT model is merely part of Cloern's phase 1, which is exemplified by studies of nutrient-chlorophyll relationships in Canadian experimental lakes (Schindler, 1977). We have not dealt with the complex indirect responses of ecosystems to enrichment and increased production, but have used the CSTT model to explore how system-specific attributes, such as exchange rate and optical conditions, determine direct response to enrichment.

The CSTT model parameter, $q$, the dynamic bulk yield of chlorophyll from limiting nutrient, was treated as a universal constant. It may not be so, either as a property of organisms or ecosystems. The numerical simulations reported in Section 4 with the Firth of Clyde model show how the value of $q$ depends on the intensity of protozoan or copepod grazing and thus how it can summarise ecosystem response to these factors (Fig. 9). Furthermore, the system response predicted by Eq. (4) of the CSTT model also depends on the source water chlorophyll concentration. Thus, blooms occurring outside RREs may overwhelm the response of an RRE to local nutrient enrichment, as proposed in Section 3.7 to explain the highest chlorophyll concentrations observed in Gullmaren and shown as discrepant in Fig. 6(b).

In the next part of this Discussion we will consider how our models need to be developed for better prediction, diagnosis and management of eutrophication in regions of restricted exchange. Using models for such purposes requires them to be well-constructed and well-proven engineering tools, and this is the long-term goal of projects 
such as OAERRE. However, we also use them as conceptual tools (in Cloern's sense) and as scientific tools for testing hypotheses about eutrophication. These uses are illustrated by Figs. 4 and 5 (conceptual model), 6(b) (scientific test of hypotheses) and 6(a) (diagnosis of trophic state).

\subsection{Developing the natural science of eutrophication models}

As discussed, there is a difference between a diagnosis of trophic status against objective criteria (Table 3), and a demonstration of anthropogenic eutrophication including identification of nutrient sources and undesirable consequences of enrichment. To be a useful tool for diagnosing and ameliorating eutrophication, the CSTT-derived model needs to be developed in two main ways. The first involves extra state variables to allow diagnosis or prediction of the undesirable consequences of increased growth of algae (and photosynthetic bacteria). The second involves considering a range of nutrient sources, especially those in the freshwater catchment of the RRE, and taking account of the social and economic effects of managing change in these sources. Extending models into the sphere of the social sciences is dealt with briefly in the third section of this discussion.

"Undesirable disturbance to the balance of organisms and the quality of the water" comprehends a range of problems, including Red Tides, water foaming, deep water and sea-bed deoxygenation, ecosystem disturbances, kills of farmed and wild marine animals, and, perhaps, shellfishvectored algal poisoning. Not all of these effects can be easily described by screening models, but a key improvement to the CSTT might be to parameterise the variable we have called $\psi$, the ratio of flagellate-dominated to total microplankton, in terms, especially, of nutrient input ratios. The underlying assumptions are that flagellates are more likely to be associated with undesirable consequences than is a microplankton dominated by diatoms, and that diatoms may become silicalimited while other algae remain nitrogen or phosphorus limited (Tett et al., in press). One way to parameterise $\psi$ would be to assume a

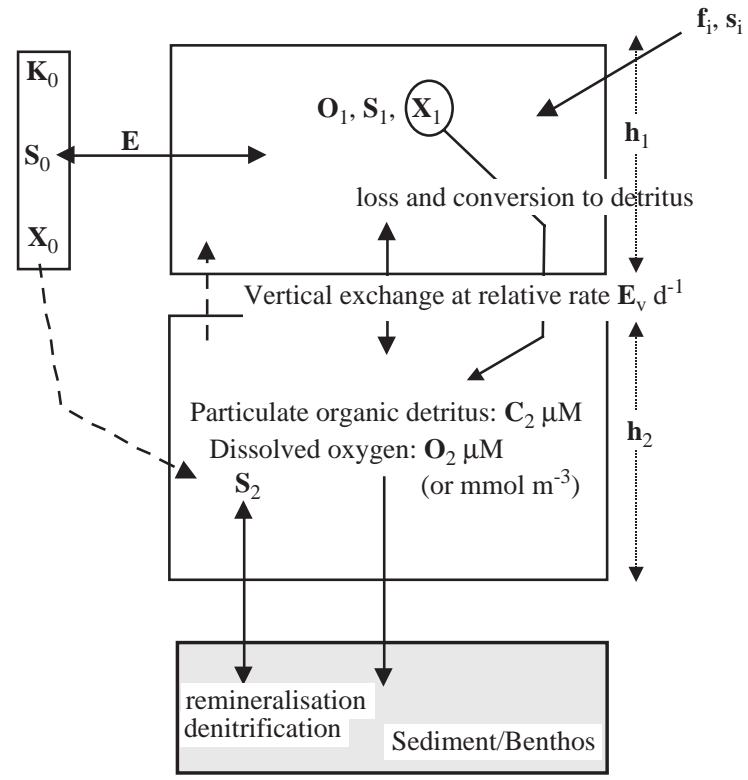

Fig. 11. Schematic of additional processes in a stratified RRE.

steady state and to suppose that the maximum diatom biomass was limited by the yield of (diatom) chlorophyll from silica, ${ }^{\mathrm{Si}} q$, so that

$$
\begin{gathered}
\psi=1-\frac{{ }^{\mathrm{Si}} q^{\mathrm{Si}} S_{e q}}{X_{\max }}, \quad \text { where } \\
{ }^{\mathrm{Si}} S_{e q}={ }^{\mathrm{Si}} S_{0}+\frac{{ }^{\mathrm{Si}} S_{i}}{E V} .
\end{gathered}
$$

Conversion of the single box of the CSTT model into a 2-layer system (Fig. 11) would allow the possibility of estimating enhanced deep-water deoxygenation by taking into account the sinking of organic particulate matter from the upper to the lower compartment. The calculation of lightlimited growth rate relative to loss rate (Eq. (5)) might allow for the ability of flagellates, especially the larger dinoflagellates, to migrate vertically in a stratified system, and of the additional losses of diatoms due to sinking under stratification. The loss term might also take account of diminished grazing by copepods on flagellates and dinoflagellates on grounds that some are too small for successful capture and others deter grazing through toxicity.

Other physical-biological models have been described with purposes broadly similar to those 
of the modified CSTT and Firth of Clyde models. Two will be briefly considered here. They are the strategic simulation model for fjords of Ross and co-workers (Ross et al., 1993, 1994), which is a dynamic model approaching the complexity of our Clyde model, and the FjordEnv model of Stigebrandt (2001) which is closer to the CSTT model.

The fjord ecosystem model of Ross et al. (1993) has three water column layers and a sediment layer. The surface and intermediate water-column layers have compartments for phytoplankton, zooplankton herbivores, and carnivores, each containing carbon and nitrogen. In the later version of the model (Ross et al., 1994), the deep layer is combined with a sediment layer as a nutrient storage compartment, the nutrients being dissolved inorganic nitrogen and dissolved organic nitrogen. Each nutrient and plankton variable is dynamic -i.e. it is described by a differential equation which includes variable terms. Water exchange is simulated by a constant, tidally forced, estuarine circulation, with only a small response to increased freshwater input.

In contrast, the FjordEnv model of Stigebrandt (2001) has more realistic parameterisations of physical processes, but resembles the modified CSTT model in using an ECE method to estimate nutrient enhancement, and assumes that all available nutrients convert to phytoplankton. However, it also, takes account of the sinking of primary production and the consequent use of oxygen in deeper water. Its continued development, and application to some of our sites, is an objective of OAERRE.

Table 7 compares key aspects of the CSTT, FjordEnv, strategic fjord simulation, and Clyde, models. The models of Ross et al. demonstrate the use of simple parameterisations of higher trophic levels. Representation of these levels may be important in adequately simulating top-down control of responses to nutrient enrichment. However, introducing dynamic predators into a model creates the possibility of Lotka-Volterra oscillations and hence of unpredictable systems (Hastings and Powell, 1991; Tett and Wilson, 2000). Ross et al. (1994) showed that such variability was damped in the case of rapidlyexchanging fjords by import and export - in effect, by increasing the strength of relaxation towards pre-determined boundary conditions. The Clyde model uses a microplankton parameterisation of the interaction between algae and protozoa in order to apply a large 'ecological viscosity' to highly dynamic microbial loop interactions, and hence damp the potential for Lotka-Volterra oscillations. Whereas the strategic fjord model requires time-series of herbivorous and carnivorous zooplankters as external boundary conditions, the Clyde model needs to be forced with a timeseries of local mesozooplankton grazing pressure. Such considerations point to the need to find a dynamic parameterisation that allows the key features of top-down control to be captured in an ecosystem model not only without rendering it impractical for engineering purposes because of extreme (i.e. chaotic) sensitivity to initial conditions or parameter values, but also without requiring substantial amounts of biological forcing data.

The CSTT model's exchange parameter $E$, and its analogue in the model of Ross et al. bundle the consequences of a variety of physical exchange processes. FjordEnv demonstrates how theoretically-based, empirically calibrated, simplified parameterisations can skilfully capture the relationship between the physical determinants of these processes, and exchange. It is our contention that models for diagnosing and managing eutrophication, which need to be both easy to use and reliable, will succeed by applying this approach to the relevant biogeochemical processes (as both FjordEnv and the CSTT models have begun to demonstrate) and, ultimately, to ecological processes involving trophic networks.

The modified CSTT model takes no account of benthic processes. FjordEnv does so only by way of an oxygen demand. In the Clyde and Ross et al. (1994) models, the lower boundary is simply a delayed-release nutrient storage compartment, without any parameterisation of benthic processes. As Cloern (2001) points out, what happens at the bottom of coastal waters can be of great importance in determining the impact of nutrient enrichment.

This is certainly true of RREs. In deep systems (those in which most of the sea bed lies below the 
Table 7

Comparison of models

\begin{tabular}{|c|c|c|c|c|}
\hline Process & CSTT + & Stigebrandt (2001) & Ross et al. $(1993,1994)$ & Clyde model \\
\hline $\begin{array}{l}\text { General } \\
\text { description }\end{array}$ & $\begin{array}{l}\text { Worst-case, steady state, } \\
\text { single-box }\end{array}$ & Dynamic, several thick layers & Dynamic, several thick layers & $\begin{array}{l}\text { Dynamic, several thick layers in } \\
\text { several basins }\end{array}$ \\
\hline $\begin{array}{l}\text { Physical } \\
\text { transports }\end{array}$ & $\begin{array}{l}\text { Summarised by exchange } \\
\text { rate, } E\end{array}$ & $\begin{array}{l}\text { Surface layer thickness, salinity } \\
\text { and flow predicted from wind } \\
\text { fresh-water and hydrography; } \\
\text { intermediate circulation driven by } \\
\text { density change at sill; wind } \\
\text { generated turbulence in surface } \\
\text { layer; wind and tidal diapycnal } \\
\text { mixing; tidal pumping with } \\
\text { efficiency }<1\end{array}$ & $\begin{array}{l}\text { Intermediate circulation seen as } \\
\text { tidally driven; upwells to cause } \\
\text { surface layer outflow; freshwater } \\
\text { volume conserved, but not a } \\
\text { driver }\end{array}$ & $\begin{array}{l}\text { Density driven estuarine } \\
\text { circulation with possible deep- } \\
\text { water replacement and diapycnal } \\
\text { mixing driven by wind, cooling, } \\
\text { bottom and internal tidal stirring; } \\
\text { tidal pumping with efficiency }<1\end{array}$ \\
\hline $\begin{array}{l}\text { Biogeochemical }^{\mathrm{a}} \\
\text { processes }\end{array}$ & $\begin{array}{l}\text { ECE for DAIN, DAIP, } \\
\text { maximum biomass set by } \\
X_{\max }=q . \text { ECE, linear } \\
\text { microplankton light-driven } \\
\text { growth, with enhanced } \\
\text { microplankton respiration; } \\
\text { other losses are constant }\end{array}$ & $\begin{array}{l}\text { ECE for P (or N); nutrient } \\
\text { completely converted to } \\
\text { phytoplankton biomass; detrital } \\
\text { sinking and first order decay, } \\
\text { with oxygen consumption }\end{array}$ & $\begin{array}{l}\text { Dynamic DAIN and DON; } \\
\text { nutrient-controlled growth is cell- } \\
\text { quota threshold limitation; } \\
\text { curvilinear phytoplankton light- } \\
\text { driven growth; detrital sinking, } \\
\text { and mineralisation only in } \\
\text { deepest layer/sea-bed, with } \\
\text { nutrient storage }\end{array}$ & $\begin{array}{l}\text { Dynamic DAIN, Silica; nutrient- } \\
\text { controlled growth is cell-quota } \\
\text { threshold limitation; linear } \\
\text { microplankton light-driven } \\
\text { growth, with enhanced } \\
\text { microplankton respiration; } \\
\text { sinking; detrital mineralisation; } \\
\text { sea-bed nutrient storage }\end{array}$ \\
\hline $\begin{array}{l}\text { Ecological } \\
\text { processes }\end{array}$ & None & None & $\begin{array}{l}\text { Phytoplankton-mesozooplankton-carnivore } \\
\text { interactions }\end{array}$ & $\begin{array}{l}\text { Diatomy and flagellatey } \\
\text { microplankton compete for N, } \\
\text { diatoms Si-limited }\end{array}$ \\
\hline
\end{tabular}

${ }^{\mathrm{a}}$ See Tett and Wilson (2000) concerning the distinction between biogeochemical and ecological processes. 
euphotic zone), benthic oxygen consumption and nutrient release need to be taken into consideration, at least in research models. In contrast, shallow sea-beds may be sites of primary production and nutrient consumption. The phytobenthos is important in the two shallowest systems studied by OAERRE, and perhaps dominant in one of these, the Ria Formosa. It might be possible to incorporate phytobenthic enrichment in a version of the CSTT model by estimating the maximum chlorophyll under unit area of the sea surface. For example,

$X_{\max }^{o}=q\left(\frac{E S_{0} h+\left(s_{i} / A\right)}{L}\right) \mathrm{mg} \mathrm{chl} \mathrm{m}^{-2}$

is a worst-case, steady state, solution for the maximum chlorophyll of firmly attached phytobenthos which do not experience loss due to water exchange, but do lose biomass at overall rate $L$ to grazers. Finally, the organic enrichment of the sediment due to nutrient-stimulated production, can bring about conditions favourable for denitrification, a process that must be included in models that aim to budget nutrients. A number of workers have described models for sediment denitrification. The approaches of DiToro (2001) and Ruardij and van_Raaphorst (1995) are particularly attractive in the present context, as they contain simplified parameterisations for 2-layered coastal sediments, in contrast to models (Rabouille and Gaillard, 1991; Middleburg et al., 1996; Soetaert et al., 1996) that fully resolve the vertical distribution of nutrients and oxidants and which are more suitable for oceanic sediments.

\subsection{Socio-economic considerations}

Turner et al. (1999) describe an interdisciplinary study of the costs and benefits of eutrophication reduction in the Baltic Sea, where nutrient loadings to the Baltic were estimated and the costs and benefits of abatement assessed.

Such a study raises three sets of issues. The first concerns matters of applied and theoretical natural science, concerning the understanding of relevant environmental processes. The second concerns economic questions of costs and benefits and how to maximise the latter in relation to the former. The third concerns how to bring about agreement amongst stakeholders (from individuals to nation states and transnational entities) in order to achieve the benefits. A factor in this process is an agreement between the stakeholders regarding the objectives regarding uses of the area (EQOs) and therefore, the establishment of the corresponding standards within limits of acceptable change.

Most of the present paper has related to OAERRE's main aim, of improving scientific understanding of the oceanographic processes that influence the impact of nutrients on RREs. Here the second and third issues in relation to a potential development of the CSTT or FjordEnv models are briefly considered. We call this development an 'Environmental State Vector' (ESV) model. The CSTT model is a solution of a dynamic model with two state variables, the concentrations of limiting nutrient and chlorophyll. This is because it is used for comparison with only two formal Environmental Quality Standards (EQSs), for winter DAIN and summer chlorophyll concentration, which are deemed sufficient to indicate ecological status in relation to nutrient inputs. Nevertheless, the set of regulatory and simulated variables may need to be expanded to adequately define 'good' environmental and ecological status. An ESV model is a general solution, consisting in any particular case of just that set of variables required to diagnose or predict whether an RRE is within or outside the range defined by a specific set of EQSs. Finally, each ESV model needs to be coupled to a catchment model to provide estimates of nutrient sources and transformations.

Following Turner et al. (1999), the next step would appear to be that of including in the ESVcatchment model some functions for the costs of nutrient reduction and the benefits of ameliorating eutrophication. However, whereas estimation of costs would seem straight-forward - the costs of waste water treatment are well-known-the estimation of benefits is more controversial. In some cases, the monetary value of ecosystem goods and services can be identified for each of a set of management scenarios, as illustrated by Glibert and Janssen's (1998) study of a mangrove ecosystem. In other cases, such as the Turner et al. study 
of the Baltic, benefits have been estimated by 'contingent value analysis' (Goffe, 1995) — asking people what they would be prepared to pay, through taxes or higher prices, for improvements in environmental quality.

While monetary value provides a convenient single variable for use in optimisation studies, this unidimensional monetarisation of ecosystem value suffers from the defects that Marx identified for 'exchange value' in chapter 1 of 'Capital'. Optimisation based on multivariate 'use value', whilst more complex, may be more suitable for conditions in Europe's 'social market' which aims to achieve the triple objectives of economic efficiency, social justice and environmental sustainability through a combination of law, taxes, planning, and negotiation as well as market forces. Doran (2001) considered the application of 'agent-based' modelling to the management of the Fraser river catchment in Canada. Such modelling can take account of all three aspects - natural scientific, economic, and socio-legalistic - of the problem of co-operative management of RRE ecosystems.

In Doran's view, the most difficult management problem is not that of finding an optimum solution based on natural science, but of defining a solution based on multidisciplinary criteria. Human society is typically comprised by a variety of stakeholders each pursuing their own interests with results that include resource depletion, pollution and social inequality (Doran, 2001). The challenge is to devise a sustainable solution which addresses interests in an equitable manner. This approach is currently being adopted in EU countries through the recent European Council Recommendation (C.E.C., 2002) concerning the implementation of Integrated Coastal Zone Management in Europe.

A number of issues are involved in managing the trophic status of RREs. Table 6 gives the proportion of equilibrium nutrient concentration in each RRE that is estimated to come from landward sources. With the exception of Kongsfjorden, at least $60 \%$ of the limiting nutrient is thus derived. In some cases the precise source can be identified (Section 3.5). Thus, about half the enhancement of nutrient in Himmerfjärden is due to the treated discharge of urban waste water, whereas in the case of Gullmaren, the Firth of Clyde and the gulf of Fos, anthropogenically enriched river discharge is the main source of nutrients. That is, whereas Himmerfjärden acts as a point source, in the other three RREs the main input sources are riverine and agriculture run-off. The CSTT model can diagnose the contribution of anthropogenic nutrients to trophic status. If that status is eutrophic, and there are undesirable consequences, the RRE can be deemed subject to eutrophication, as discussed in Section 2.3.

Should a RRE be so identified, the provisions of article 5 of the Urban Waste Water Treatment Directive come into play, and direct discharges must be nutrient-stripped, as is already the case in Himmerfjärden. However, although the UWWTD requires treatment of discharges of waste water into rivers, it has no powers to control agricultural leaching or most forms of aquacultural input of nutrients. The Nitrates Directive (C.E.C., 1991b) places some constraint on fertiliser use in 'nitrate vulnerable zones' (NVZ). In addition, NVZ, and consequent land-use restrictions, may need to be designated in fresh-waters if these are deemed as potentially eutrophic or sources of nutrient to potentially eutrophic coastal areas (European Commission Court of Justice, Judgement of Court (Sixth Chamber), June 27, 2002). Finally, the Water Framework Directive requires the maintenance or restoration of 'good' ecological status and thus in principle can demand severe reductions in diffuse inputs of nitrogen and phosphorus to rivers and estuaries, and to RREs themselves, when the nutrient enrichment results in eutrophication.

In addition to the existence of natural nutrient sinks in rivers and estuaries (Billen et al., 1991), which can be augmented by the creation or restoration of wetlands (Turner et al., 1999), RREs are in most cases able to dispose of substantial nutrient inputs without adverse environmental impact. Nutrient-nitrogen is dispersed, denitrified or buried; nutrient-phosphorus is dispersed or buried. As pointed out by Elmgren (1997), the Himmer fjord acts as an extra sewage treatment plant for the quarter of a million people whose waste discharges there. The fjord may thus be seen, in principle, as a financially valuable 
Table 8

Categories of human activity in an RRE and its catchment

\begin{tabular}{|c|c|c|}
\hline Activity & Time-scale of variation & Notes \\
\hline Agriculture and forestry & Seasonal and long-term & $\begin{array}{l}\text { Nutrient inputs due to leaching from } \\
\text { soil and disposal of farmyard wastes }\end{array}$ \\
\hline Industry & Long-term & $\begin{array}{l}\text { Nutrient input depends on type of } \\
\text { industry }\end{array}$ \\
\hline Fishery & Seasonal and long-term & $\begin{array}{l}\text { May be necessary to distinguish } \\
\text { recreational from commercial fishery; } \\
\text { removes nutrients in fish, may change } \\
\text { sea bed }\end{array}$ \\
\hline Aquaculture & Seasonal and long-term & $\begin{array}{l}\text { Finfish aquaculture inputs nutrients, } \\
\text { shellfish aquaculture removes } \\
\text { phytoplankton }\end{array}$ \\
\hline Permanent inhabitants & Long-term & $\begin{array}{l}\text { Inputs nutrients depending on level of } \\
\text { UWW treatment }\end{array}$ \\
\hline Temporary inhabitants & Seasonal & $\begin{array}{l}\text { Inputs nutrients depending on level of } \\
\text { UWW treatment }\end{array}$ \\
\hline Water manipulation & Seasonal and long-term & $\begin{array}{l}\text { Requirements (for water and } \\
\text { hydroelectricity) driven by other } \\
\text { activities; damming and abstraction } \\
\text { changes seasonal pattern and nutrient } \\
\text { concs. }\end{array}$ \\
\hline
\end{tabular}

resource. Quantification of this resource requires (a) estimating the degree of sewage treatment required to meet a prescribed EQS in the adjacent coastal waters, and (b) costing the building and maintenance costs for the amount of treatment provided by the plant. Of course, there is a limit to the use that can be made of an RRE for this purpose, and this limit itself is set (or could be set) by EQS relating to a diagnosis of eutrophication. Nevertheless, the point is that the nutrientabsorbing capabilities of RREs have a value and this value is currently used by some social groups (such as farmers and fish farmers) without payment, whereas other groups (such as city dwellers) have to pay additional costs because they cannot use these capabilities.

Scientific study of RREs can explore the relevant natural processes, and a univariate or multivariate economic model can provide rules for potential optimisation. However, such work cannot itself reconcile conflicting interests. This case exemplifies the sort of problem for which solutions might be explored with an agent-based model.

Such a model would need to deal with the RRE and its catchment, which in most cases is the main source of nutrient enrichment. States and pro- cesses external to this catchment (sea boundary conditions, atmospheric inputs, macro-economic trends) would be treated as constants. Seven aggregated categories of human activity (Table 8 ) within the catchment and RRE may be considered. These interact directly with each other-for example by competing for land-and indirectly through the catchment ecosystems. Each category would be represented by a submodel (population of software agents) obeying rules for functional behaviour and for communication with other submodels (agents).

The RRE itself provides an 8th category. Its submodels (population of agents) would correspond, in principle, to state variables with 'intentionality'-i.e. constrained by the software to find an optimum solution that places the value of each within a corresponding EQS. These agents are governed by a set of scientifically-validated rules, are influenced by human activities (nutrient loading) and in turn influence these activities by way of environmental quality.

Considering such a model provides a useful conceptual exercise. However, as Doran (2001) pointed out, no such model has as "yet been implemented on a computer, and indeed is quite 
far from implementation ...". A more feasible task is that of developing an ESV model that can provide part of the 'natural environmental submodel' in Doran's scheme. Doran argued that such a submodel must "capture the need for long-term co-operation to attain sustainability ... [and] should also permit the issue of equality or inequality of agent access to resources to be addressed ...". An ESV model coupled to a catchment model for nutrient sources could embody such properties.

\section{Conclusions}

Understanding the process of anthropogenic eutrophication is particularly important in the context of applying legislation such as the Water Framework Directive (WFD). It is useful to distinguish between eutrophic status, which the WFD approves if natural, and the human-driven process that can lead to this status, which should be ameliorated. The OAERRE project aims to increase understanding of the processes controlling trophic status in coastal regions of restricted exchange, including those leading to the 'undesirable consequences' that form part of the UWWTD's definition of eutrophication. However, this paper, first drafted a year after the commencement of the project, has focused on the first two parts of the UWWTD definition, those concerning nutrient status and amount of phytoplankton.

Comparison of measurements at the six project sites (Kongsfjorden; Gullmaren; Himmerfjärden; Firth of Clyde; Golfe de Fos; Ria Formosa) with the environmental quality standards defined by the UK CSTT (1994, 1997) indicated that Gullmaren and Golfe de Fos could be considered eutrophic. However, occasional extremes can strongly control this assessment, and the weakness of a purely empirical appraisal is shown by the lack of a clear relationship between nutrient loading and trophic stated indicators in Fig. 2.

The OAERRE project aims to supplement an empirical approach by developing and applying simple 'screening' models which both diagnose and predict eutrophication and also help clarify the key environmental controls on trophic state. These models include the FJORDENV and CSTT models. This paper has focused on the CSTT model, which assumes a region of restricted exchange to be a well mixed box exchanging with the sea at a daily rate $E$ and converting nutrient to chlorophyll at a fixed rate $q$.

When applied to the OAERRE sites (Fig. 6(a)), the CSTT model diagnosed only the inner region of Himmer fjord as potentially eutrophic. However, summer chlorophyll concentrations observed in the fjord do not attain the levels predicted; the model's assumed loss rate may have been too low, indicating that there are controls on trophic status which need better parameterisation in screening models. Furthermore, there were discrepancies between observed and predicted maximum chlorophyll (Fig. 6(b)) in the cases of the gulf of Fos and the Gullmar fjord. These discrepancies probably demonstrate the difficulty of estimating the size of the box which in the CSTT model receives nutrients, or of getting good statistics for boundary conditions. A particular issue raised in relation to extreme statistics concerns the level of extreme to enter into the model: should it be the summer maximum in a typical year, or the greatest value observed, for example, during one year in ten?

The simplicity of the current version of the CSTT model limits its efficacy as a tool for diagnosing and predicting trophic status; developments are required. Simulations of a more complex 'research' model for the Firth of Clyde were used to study the influence of various factors on the yield $(q)$ of chlorophyll from nutrient, a key feature of the CSTT model. These studies indicate the importance of microheterotrophic activity (Fig. 9) and demonstrate variation in exchange rate (Fig. 10). The first point emphasises the possibly important role of planktonic protozoans in limiting algal growth, and the second point shows the need to understand the variety of physical processes involved in exchange in RREs. OAERRE is studying both these matters in detail, seeking parameters such as $\eta$ which summarise the relationship between planktonic autotrophs and microheterotrophs, and considering how exchange rate $(E)$ in the CSTT model can be related to physical variability. 
In the final section of this paper we considered improvements to the natural science of screening models and how, in principle, such models might take account of social and economic considerations. Suggested modifications to the CSTT model include the use of silica loading in order to discriminate between diatoms and flagellates, and the addition of a second layer allowing sedimentation and deep water oxygen depletion. Assuming that flagellates are more likely to be associated with the undesirable consequences of eutrophication, such developments could go beyond the prediction of chlorophyll to give insights into the undesirable consequences of nutrient enrichment. There is also a need to take account of benthicpelagic interactions in shallow systems, especially that of the Ria Formosa.

The deterioration of an aquatic system has social and economic implications, and its restoration has costs. Conversely, the ability of an RRE to absorb anthropogenic nutrients without detectable harm can be seen as a resource, which can be given a monetary value. Optimising the use of this resource can be seen as analogous to the problem of optimising the fit of model simulations to a set of observations. We have briefly compared scalar (exchange value, monetary equivalence, contingent valuation) and vector (use-value, multiple environmental quality variables and standards) methodologies for optimising use of environmental resources, and conclude that the latter are most applicable in the European 'social market' environment.

\section{Acknowledgements}

The authors acknowledge part-funding of the OAERRE project by contract EVK3-CT199900002. This is ELOISE publication no. 434/34. We are grateful to Dr. R. Gowen and an anonymous referee for helpful comments.

\section{References}

Adams, J.A., 1986. Zooplankton investigations in the Firth of Clyde. Proceedings of the Royal Society of Edinburgh 90B, 239-254.
Allen, J.R., Slinn, D.J., Shammon, T.M., Hartnoll, R.G., Hawkins, S.J., 1998. Evidence for the eutrophication of the Irish Sea over four decades. Limnology and Oceanography 43, 1970-1974.

Arfi, R., 1984. Gulf of Fos (France): main hydrobiological features (1976-1978). Hydrobiologia 118, 187-194.

Arfi, R., Gaudy, R., Kerambrun, P., Pagano, M., 1990. Plasticité écologique des populations planctoniques à 1'interface terre-mer. Conditions naturelles, effets anthropiques (356-360). Compte rendu EUROCOAST-Littoral 1990, 764pp.

Barton, E.D., Arístegui, J., Tett, P., Cantón, M., García-Braun, J.A., Hernández-Leon, S., et al., 1998. The transition zone of the Canary Current upwelling region. Progress in Oceanography $41,457-503$.

Benon, P., Bourgade, B., Kantin, R., 1977. Impact de la pollution sur les Ecosystemes mediterraneens cotiers: aspects planctoniques. These 3eme cycle, Univ de la Mediterranee. Thèse 3 ème cycle, Université de la Méditerranée.

Billen, G., Lancelot, C., Meybeck, M., 1991. N, P and Si retention along the aquatic continuum from land to ocean. In: Mantoura, R.F.C., Martin, J.-M., Wollast, R. (Eds.), Ocean Margin Processes in Global Change. Wiley, New York, pp. 19-44.

Blomqvist, S., Larsson, U., 1997. Sediment och sedimentation. In: Elmgren, R., Larsson, U. (Eds.), Himmerfjärden Naturvårdsverket Förlag, Stockholm, Rapport 4565, pp. 98-109.

Bock, M.T., Miller, B.S., Bowman, A.W., 1999. Assessment of eutrophication in the Firth of Clyde: analysis of coastal water data from 1982 to 1996. Marine Pollution Bulletin 38, 222-231.

Bowers, D.G., Harker, G.E.L., Smith, P.S.D., Tett, P., 2000. Optical properties of a region of freshwater influence (the Clyde Sea). Estuarine, Coastal and Shelf Science 50, 717-726.

C.E.C., 1991a. Council Directive of 21 May 1991 concerning urban waste water treatment (91/271/EEC). Official Journal of the European Communities L135, 40-52 (30.5.91).

C.E.C., 1991b. Council Directive 91/676/EEC of 12 December 1991 concerning the protection of waters against pollution caused by nitrates from agricultural sources. Official Journal of the European Communities L 375, 1-8 (31.12.91).

C.E.C., 2000. Directive 2000/60/EC of the European Parliament and of the Council of 23 October 2000 establishing a framework for Community action in the field of water policy. Official Journal of the European Communities L $327,1-73(22.12 .2000)$.

C.E.C., 2002. Recommendation of the European Parliament and of the Council of 30 May 2002 concerning the implementation of Integrated Coastal Zone Management in Europe (2002/413/EC). Official Journal of the European Communities L 148, 24-27 (6.6.2002).

Caetano, M., Ferreira, J.G., Icely, J., Newton, A., Nunes, J.P., Vale, C., 2002. Ria Formosa. In: Gilpin, L., Tett, P. (Eds.), 
OAERRE Sites Description Report. Napier University, Edinburgh.

Caperon, J., Meyer, J., 1972. Nitrogen-limited growth of marine phytoplankton-I. Changes in population characteristics with steady-state growth rate. Deep-Sea Research 19, 601-618.

Cloern, J.E., 2001. Our evolving conceptual model of the coastal eutrophication problem. Marine Ecology-Progress Series 10, 223-253.

CSTT, 1994. Comprehensive studies for the purposes of Article 6 of DIR 91/271 EEC, the Urban Waste Water Treatment Directive. Published for the Comprehensive Studies Task Team of Group Coordinating Sea Disposal Monitoring by the Forth River Purification Board, Edinburgh.

CSTT, 1997. Comprehensive studies for the purposes of Article $6 \& 8.5$ of DIR 91/271 EEC, the Urban Waste Water Treatment Directive, second edition. Published for the Comprehensive Studies Task Team of Group Coordinating Sea Disposal Monitoring by the Department of the Environment for Northern Ireland, the Environment Agency, the Scottish Environmental Protection Agency and the Water Services Association, Edinburgh.

Dillon, P.J., Rigler, F.H., 1974. The phosphorus-chlorophyll relationship in lakes. Limnology and Oceanography 19, 767-773.

DiToro, D.M., 2001. Sediment flux modelling. Wiley InterScience, New York.

Doran, J., 2001. Intervening to achieve co-operative ecosystem management: towards an agent based model. Journal of Artificial Societies and Social Simulation, 4: http:// www.soc.surrey.ac.uk/JASSS/4/2/4.html.

Downing, J.A., Osenberg, C.W., Sarnelle, O., 1999. Metaanalysis of marine nutrient-enrichment experiments: variation in the magnitude of nutrient limitation. Ecology 80, 1157-1167.

Droop, M.R., 1983. 25 years of algal growth kinetics - a personal view. Botanica Marina 26, 99-112.

Edler, L., 1997. In: Report of the ICES/HELCOM Workshop on Quality Assurance of pelagic biological measurements in the Baltic Sea. ICES CM, 1997/E:5.

Edwards, V.R., 2001. The yield of marine phytoplankton chlorophyll from dissolved inorganic nitrogen under eutrophic conditions. Ph.D. Thesis, Napier University, Edinburgh.

Edwards, A., Baxter, M.S., Ellett, D.J., Martin, J.H.A., Meldrum, D.T., Griffiths, C.R., 1986. Clyde Sea hydrography. Proceedings of the Royal Society of Edinburgh 90B, $67-83$.

Elliott, A.J., Li, Z., 1995. A model of the annual cycle of temperature in the north-west European shelf seas with stochastic wind forcing. Estuarine, Coastal and Shelf Science 40, 265-280.

Elmgren, A., 1997. Himmerfjärden: changes in a nutrient enriched coastal ecosystem (english summary of the report). In: Elmgren, R., Larsson, U. (Eds.), Himmerfjärden. Naturvårdsverket Förlag, Stockholm, Rapport 4565, pp. 13-18.
Elmgren, R., Larsson, U. (Eds.), 1997. Himmerfjärden. Naturvårdsverket Förlag, Stockholm, Rapport 4565.

Engqvist, A., 1997. Vatten- och närsltutbyte i hela Himmerfjärden. In: Elmgren, R., Larsson, U. (Eds.), Himmerfjärden. Naturvårdsverket Förlag, Stockholm, Rapport 4565, pp. 120-143.

Erlandsson, C.P., Arneborg, L., 2002. In: Gilpin, L., Tett, P. (Eds.), Gullmar Fjord. OAERRE Sites Description Report. Napier University, Edinburgh.

Folack, J., 1986. Variations mensuelles de la biomasse et de la production du phytoplancton d'une zone côtière d'intérêt aquicole: Anse de Carteau - Golfe de Fos. Thèse 3 ème cycle, Université de la Méditerranée.

Foy, R.H., 1992. A phosphorous loading model for Northern Irish Lakes. Water Research 26, 633-638.

Gerlach, S.A., 1990. Nitrogen, phosphorus, plankton and oxygen deficiency in the German Bight and in Kiel Bay. Kieler Meeresforschungen, Sonderheft 7, 1-341.

GESAMP, 1996. (IMO/FAO/Unesco-IOC/WMO/WHO/ IAEA/UN/UNEP Joint Group of Experts on the Scientific Aspects of Marine Environmental protection) Monitoring the ecological effects of coastal aquaculture wastes. Food and Agricultural Organization of the United Nations, Rome, Reports and Studies by GESAMP, vol. 57, 38pp.

Gillbricht, M., 1988. Phytoplankton and nutrients in the Helgoland region. Helgolander Meeresuntersuchungen 42, 435-467.

Gillibrand, P.A., Turrell, W.R., 1997. The use of simple models in the regulation of the impact of fish farms on water quality in Scottish sea lochs. Aquaculture 159, 33-46.

Glibert, A.J., Janssen, R., 1998. Use of environmental functions to communicate the values of a mangrove ecosystem under different management regimes. Ecological Economics 25, 323-346.

Goffe, P., 1995. The benefits of improvements in coastal water quality: a contingent approach. Journal of Environmental Management 45, 305-317.

Gowen, R.J., 1994. Managing eutrophication associated with aquacultural development. Journal of Applied Ichthyology 10, 242-257.

Gowen, R.J., Ezzi, I., 1992. Assessment and prediction of the potential for hypernutrification and eutrophication associated with cage cultures of salmonids in Scottish coastal waters. NERC, Dunstaffnage Marine Laboratory, Oban, Argyll, Scotland, 136pp.

Gowen, R.J., Tett, P., Wood, B.J.B., 1983. Changes in the major dihydroporphyrin plankton pigments during the spring bloom of phytoplankton in two Scottish sea-lochs. Journal of the Marine Biological Association of the United Kingdom 63, 27-36.

Gowen, R.J., Tett, P., Jones, K.J., 1992. Predicting marine eutrophication: the yield of chlorophyll from nitrogen in Scottish coastal phytoplankton. Marine Ecology_-Progress Series 85, 153-161.

Gowen, R.J., Hydes, D.J., Mills, D.K., Stewart, B.M., Brown, J., Gibson, C.E., Shammon, T.M., Alien, M., Malcolm, S.J., 2002. Assessing trends in nutrient concentrations in coastal 
shelf seas: a case study in the Irish Sea. Estuarine, Coastal and Shelf Science 54, 827-939.

Grantham, B., Tett, P., 1993. The nutrient status of the Clyde Sea in winter. Estuarine, Coastal and Shelf Science 36, $449-462$.

Grenz, C., 2002. Golfe de Fos. In: Gilpin, L., Tett, P. (Eds.), OAERRE Sites Description Report. Napier University, Edinburgh.

Haig, A.J.N., 1986. Use of the Clyde estuary and Firth for the disposal of effluents. Proceedings of the Royal Society of Edinburgh 90B, 393-405.

Hansen, O.S., Ærtegbjerg, G., Molvær, J., Magnusson, J., 2001. Eutrophication, current status and development. In: Karlson, B., Håkansson, B., Sjöberg, B. (Eds.), SkagerrakEnvironmental State and Monitoring Prospects. Swedish Meteorological and Hydrological Institute, Göteborg, pp. 13-45.

Hastings, A., Powell, T., 1991. Chaos in a three-species food chain. Ecology 72, 896-903.

Hecky, R.E., Kilham, P., 1988. Nutrient limitation of phytoplankton in freshwater and marine environments: a review of recent evidence on the effects of enrichment. Limnology and Oceanography 33, 796-822.

Holmes, R.W., 1970. The Secchi disk in turbid coastal zones. Limnology and Oceanography 15, 688-694.

Hop, H., Pearson, T., Hegseth, E.N., Kovacs, K.M., Wiencke, C., Kwasniewski, S., et al., 2002. The marine ecosystem of Kongsfjorden. Svalbard. Polar Research 21, 167-208.

Janzen, C.D., Simpson, J.H., Cottier, F., 2002. Frontal controls on the cross-sill exchange of a broad fjord. AGU/ASLO Ocean Sciences Meeting, Honolulu, HI; EOS Transactions AGU 83 (4), OS358.

Jassby, A.D., Platt, T., 1976. Mathematical formulation of the relationship between photosynthesis and light for phytoplankton. Limnology and Oceanography 21, 540-547.

Jones, K.J., Tett, P., Wallis, A.C., Wood, B.J.B., 1978. Investigation of a nutrient-growth model using a continuous culture of natural phytoplankton. Journal of the Marine Biological Association of the United Kingdom 58, 923-941.

Jones, K.J., Grantham, B., Ezzi, I., Rippeth, T., Simpson, J., 1995. Physical contols on phytoplankton and nutrient cycles in the Clyde Sea, a fjordic system on the west coast of Scotland. In: Skjoldal, H.R., Hopkins, C., Erikstad, K.E., Leinass, H.P. (Eds.), Ecology of Fjords and Coastal Waters. Elsevier, Amsterdam, pp. 93-104.

Justic, D., Rabalais, N.N., Turner, R.E., 1995. Stoichiometric nutrient balance and origin of coastal eutrophication. Marine Pollution Bulletin 30, 41-46.

Kasai, A., Rippeth, T.H., Simpson, J.H., 1999. Density and flow structure in the Clyde Sea front. Continental Shelf Research 19, 1833-1848.

Kratzer, S., 2000. Bio-optical studies of coastal waters. Ph.D. Thesis, University of Wales, Bangor.

Larsson, U., 1997. Tidstrender. In: Elmgren, R., Larsson, U. (Eds.), Himmerfjärden. Naturvårdsverket Förlag, Stockholm, Rapport 4565.
Larsson, U., Engqvist, A., 1997. Material transport till Himmerfjärdens inre bassäng. In: Elmgren, R., Larsson, U. (Eds.), Himmerfjärden. Naturvärdsverket Förlag, Stockholm, Rapport 4565, pp. 144-158.

Larsson, U., Kratzer, S., 2002. Himmerfjärden In: Gilpin, L., Tett, P. (Eds.), OAERRE Sites Description Report, Vol. 2. Napier University, Edinburgh, pp. 33-43.

Le Gall, A.C., Hydes, D.J., Kelly-Gerreyn, B., Slinn, D.J., 2000. Development of a 2D horizontal biogeochemical model for the Irish Sea DYMONIS. ICES Journal of Marine Science 57, 1050-1059.

Lederman, T.C., Tett, P., 1981. Problems in modelling the photosynthesis-light relationship for phytoplankton. Botanica Marina 24, 125-134.

Lee, J.-Y., 2002. A coupled physical-biological model of the Firth of Clyde. Ph.D. Thesis, Napier University, Edinburgh.

Lee, J.-Y., Tett, P., Jones, K., Jones, S., Luyten, P., Smith, C., Wild-Allen, K., 2002. The PROWQM physical-biological model with benthic-pelagic coupling applied to the northern North Sea. Journal of Sea Research 48, 287-331.

Levasseur, M., Thompson, P.A., Harrison, P.J., 1993. Physiological acclimation of marine phytoplankton to different nitrogen sources. Journal of Phycology 29, 587-595.

Lindahl, O., 1987. Plankton community dynamics in relation to water exchange in the Gullmar Fjord, Sweden. Ph.D. Thesis, University of Stockholm.

Lindahl, O., 1994. Long-term studies of primary production in the Gullmar Fjord, Sweden. In: Skjordal, H.R., Hopkins, C., Erikstad, K.E., Leinaas, H.P. (Eds.), Ecology of Fjords and Coastal Waters. Elsevier, Amsterdam, pp. 105-112.

Luyten, P.J., Jones, J.E., Proctor, R., Tabor, A., Tett, P., WildAllen, K., 1999. COHERENS - a coupled hydrodynamicalecological model for regional and shelf seas: user documentation. Management Unit of the Mathematical Models of the North Sea, MUMM Internal Document, $911 \mathrm{pp}$.

Mantoura, R.F.C., Jeffrey, S.W., Llewellyn, C.A., Claustre, H., Morales, C.E., 1997. Comparison between spectrophotometric, fluorometric and HPLC methods for chlorophyll analysis. In: Jeffrey, S.W., Mantoura, R.F.C., Wright, S.W. (Eds.), Phytoplankton Pigments in Oceanography. UNESCO, Pairs, pp. 361-380.

Middleburg, J.J., Soertaert, K., Herman, P.J., Heip, C.H.R., 1996. Denitrification in marine sediments: a model study. Global Biogeochemical Cycles 10, 661-673.

Midgely, R.P., 1998. Circulation, mixing and renewal in the Clyde Sea. Ph.D. Thesis, University of Wales, Bangor.

Midgely, R.P., Simpson, J.H., Hyder, P., Rippeth, T.P., 2001. Seasonal cycle of vertical structure and deep water renewal in the Clyde Sea. Estuarine, Coastal and Shelf Science 53, 813-823.

Millot, C., 1991. Mesoscale and seasonal variabilities of the circulation in the western Mediterranean. Dynamics of Atmospheres and Oceans 15, 179-214.

Muller, F.L.L., Balls, P.W., Tranter, M., 1995. Annual geochemical mass balances in waters of the Firth of Clyde. Oceanologica Acta 18, 5. 
Newton, A., Icely, J.D., Falcão, M., Nobre, A., Nunes, J.G., Ferreira, J.G., Vale, C., 2003. Evaluation of eutrophication in the Ria Formosa coastal lagoon, Portugal. Continental Shelf Research, this issue (doi:10.1016/j.csr.2003.06.008).

Nixon, S.W., 1995. Coastal marine eutrophication: a definition, social causes, and future concerns. Ophelia 41, 199-219.

OECD, 1982. Eutrophication of Waters, Monitoring, Assessment and Control. Organisation for Economic Cooperation and Development, Paris.

Officer, C.B., 1976. Physical Oceanography of Estuaries. Wiley, New York.

Officer, C.B., Ryther, J.H., 1980. The possible importance of silicon in marine eutrophication. Marine Ecology_Progress Series 3, 89-91.

OSPAR, 2001a. Draft Common Assessment Criteria and their Application within the Comprehensive Procedure of the Common Procedure. Meeting of The Eutrophication Task Group, London, 9-11 October 2001, Annex 5. Ospar Convention For The Protection of The Marine Environment of The North-East Atlantic.

OSPAR, 2001b. First Proposal for Integrating the OSPAR Common Procedure and the Water Framework Directive with respect to Eutrophication. Meeting of The Eutrophication Task Group, London, 9-11 October 2001, Annex 6. Ospar Convention For The Protection of The Marine Environment of The North-East Atlantic.

Prieur, L., Sathyendranath, S., 1981. An optical classification of coastal and oceanic waters based on the specific spectral absorption curves of phytoplankton pigments, dissolved organic matter, and other particulate materials. Limnology and Oceanography 26, 671-689.

Rabouille, C., Gaillard, J.-F., 1991. Towards the EDGE: Early diagenetic global explanation. A model depicting the early diagenesis of organic matter, $\mathrm{O}_{2}, \mathrm{NO}_{3}, \mathrm{Mn}$ and $\mathrm{PO}_{4}$. Geochimica and Cosmochimica Acta 55, 2511-2525.

Raymont, J.E.G., 1980. Plankton and productivity in the oceans, 2nd edition, vol. 1. Phytoplankton, Pergamon, Oxford.

Rippeth, T., 1993. The control of stratification in a fjordic system (the Clyde Sea). Ph.D. University of Wales, Bangor.

Rippeth, T.P., Jones, K.J., 1997. The seasonal cycle of nitrate in the Clyde Sea. Journal of Marine Systems 12, 299-310.

Rippeth, T.P., Midgely, R.P., Simpson, J.H., 1995. The seasonal cycle of stratification in a Scottish fjord. In: Skjoldal, H.R., Hopkins, C., Erikstad, K.E., Leinass, H.P. (Eds.), Ecology of Fjords and Coastal Waters. Elsevier, Amsterdam.

Rodhe, W., 1969. Crystallization of eutrophication concepts in northern Europe. In: Rohlich, G.A. (Ed.), Eutrophication: Causes, Consequences, Correctives. National Academy of Sciences, Washington, DC, pp. 50-64.

Ross, A.H., Gurney, W.S.C., Heath, M.R., Hay, S.J., Henderson, E.W., 1993. A strategic simulation model of a fjord ecosystem. Limnology and Oceanography 38, $128-153$.
Ross, A.H., Gurney, W.S.C., Heath, M.R., 1994. A comparative study of the ecosystem dynamics of 4 fjords. Limnology and Oceanography 39, 318-343.

Ruardij, P., van_Raaphorst, W., 1995. Benthic nutrient regeneration in the ERSEM ecosystem model of the North Sea. Netherlands Journal of Sea Research 33, 453-483.

Ryther, J.H., Dunstan, W.M., 1971. Nitrogen, phosphorus and eutrophication in the inshore marine environment. Science 171, 1008-1013.

Sakshaug, E., Andresen, K., Kiefer, D.A., 1989. A steady state description of growth and light absorption in the marine planktonic diatom Skeletonema costatum. Limnology and Oceanography 34, 198-205.

Sanden, P., Håkansson, B., 1996. Long-term trends in the Secchi depth in the Baltic Sea. Limnology and Oceanography 41, 346-351.

Schindler, D.W., 1977. Evolution of phosphorus limitation in lakes. Science 195, 260-262.

Schindler, D.W., Fee, E.J., Ruszczynski, T., 1978. Phosphorus input and its consequences for phytoplankton standing crop in the Experimental Lake Area and in similar lakes. Journal of the Fisheries Research Board of Canada 35, 190-196.

Seitzinger, S.P., 1988. Denitrification in freshwater and coastal marine ecosystems: Ecological and geochemical consequences. Limnology and Oceanography 33, 702-724.

Simpson, J.H., Rippeth, T.P., 1993. The Clyde Sea: a model of the seasonal cycle of stratification and mixing. Estuarine, Coastal and Shelf Science 37, 129-144.

Soederstroem, J., 1996. The significance of observed nutrient concentrations in the discussion about nitrogen and phosphorus as limiting nutrients for the primary carbon flux in coastal water ecosystems. Sarsia 81, 81-96.

Soetaert, K., Herman, P.M.J., Middelburg, J.J., 1996. A model of early diagenetic processes from the shelf to abyssal depths. Geochimica et Cosmochimica Acta 60, 1019-1040.

Sosik, H.M., Mitchell, B.G., 1991. Absorption fluorescence and quantum yield for growth in nitrogen limited Dunaliella tertiolecta. Limnology and Oceanography 36, 910-921.

Sosik, H.M., Mitchell, B.G., 1994. Effects of temperature on growth, light absorption, and quantum yield in Dunaliella tertiolecta (Chlorophyceae). Journal of Phycology 30, 833-840.

Stigebrandt, A., 1976. Vertical diffusion driven by internal waves in a sill fjord. Journal of Physical Oceanography 6, 486- 495 .

Stigebrandt, A., 2001. FJORDENV - a water quality model for fjords and other inshore waters. Earth Sciences Centre, Göteborg University, Göteborg, C40 2001, 41pp.

Stigebrandt, A., Aure, J., 1979. Observational evidence for vertical diffusion driven by internal waves of tidal origin in the Oslofjord. Journal of Physical Oceanography 9, 435-441.

Svansson, A., 1984. Hydrography of the Gullmar Fjord. Institute of Hydrographic Research, Göteborg, Report, 23.

Svendsen, H., Beszczynska-Møller, A., Hagen, J.O., Lefauconnier, B., Tverberg, V., Gerland, S., Ørbæk, J.B., Bischof, K., Papucci, C., Zajaczkowksi, M., Azzolini, R., Bruland, O., 
Wiencke, C., Winther, J.-G., Dallmann, W., 2002. The physical environment of Kongsfjorden-Krossfjorden, an Arctic fjord system in Svalbard. Polar Research 21, 133-166.

Taylor, D., Nixon, S., Granger, S., Buckley, B., 1995. Nutrient limitation and the eutrophication of coastal lagoons. Marine Ecology_Progress Series 127, 235-244.

Tett, P., 1990. The photic zone. In: Herring, P.J., Campbell, A.K., Whitfield, M., Maddock, L. (Eds.), Light and Life in the Sea. Cambridge University Press, Cambridge, UK, pp. 59-87.

Tett, P., 1998. Parameterising a microplankton model. Napier University, Edinburgh, Report.

Tett, P., 2000. Marine eutrophication and the use of models. In: Huxham, M., Summer, D. (Eds.), Science and Environmental Decision Making. Addison-Wesley Longman/Pearson Education, London, pp. 215-238.

Tett, P., Grenz, C., 1994. Designing a simple microbiologicalphysical model for a coastal embayment. Vie et Milieu 44, 39-58.

Tett, P., Walne, A., 1995. Observations and simulations of hydrography, nutrients and plankton in the southern North Sea. Ophelia 42, 371-416.

Tett, P., Wilson, H., 2000. From biogeochemical to ecological models of marine microplankton. Journal of Marine Systems 25, 431-446.

Tett, P., Heaney, S.I., Droop, M.R., 1985. The Redfield ratio and phytoplankton growth rate. Journal of the Marine Biological Association of the United Kingdom 65, 487-504.

Tett, P., Arístegui, J., Barton, D., Basterretxea, G., De Armas, J.D., Escánez, J.E., Hernández León, S., Lorenzo, L.M.,
Montero, N., 2002. Steady-state DCM dynamics in Canaries waters. Deep-Sea Research II 49, 3543-3559.

Tett, P., Hydes, D., Sanders, R., Influence of nutrient biogeochemistry on the ecology of North-West European shelf seas. In: Schimmield, G., Black, K. (Eds.), Biogeochemistry of Marine Systems. Sheffield Academic Press Ltd., Sheffield, in press.

Thingstad, T.F., Zweifel, U.L., Rassoulzadegan, F., 1998. P limitation of heterotrophic bacteria and phytoplankton in the northwest Mediterranean. Limnology and Oceanography 43, 88-94.

Turner, R.K., Georgiou, S., Gren, I.M., Wulff, F., Scott, B., Soderqvist, T., et al., 1999. Managing nutrient fluxes and pollution in the Baltic: an interdisciplinary simulation study. Ecological Economics 30, 333-352.

Ulses, C., 2002. Modélisation tridimensionnelle de la circulation dans le golfe de Fos. Rapport DEA, Université de la Méditerranée, Marseille.

Vollenweider, R.A., 1976. Advances in defining critical loading levels for phosphorus in lake eutrophication. Memorie dell'Istituto Italiano di Idrobiologia 33, 53-83.

Vollenweider, R.A., 1992. Coastal marine eutrophication: principles and control. The Science of the Total Environment 63 (suppl.), 1-20.

Wulff, F., Rahm, L., Rodriguez-Medina, M., 1994. Longterm and regional variations of nutrients in the Baltic Sea: 1972-1991. Finnish Marine Research 262, 35-50.

Zehr, J.P., Falkowski, P.G., Fowler, J., Capone, D.G., 1988. Coupling between ammonium uptake and incorporation in a marine diatom: experiments with the short-lived radioisotope ${ }^{13} \mathrm{~N}$. Limnology and Oceanography 33, 518-527. 